\title{
Reconstruction of atmospheric lead and heavy metal pollution in the Otrębowskie Brzegi peatland (S Poland)
}

\author{
Fatima PAWEŁCZYK ${ }^{1, ~ *}$, Karolina BLOOM², Witold JUCHA ${ }^{3}$, Adam MICHCZYŃSKI ${ }^{1}$, Daniel OKUPNY ${ }^{3}$, \\ Jarosław SIKORSKI ${ }^{1}$, Julita TOMKOWIAK ${ }^{2}$, Ewelina ZAJĄC ${ }^{4}$ and Nathalie FAGEL ${ }^{5}$ \\ 1 Silesian University of Technology, Institute of Physics - Centre for Science and Education, Konarskiego 22B, 44-100 \\ Gliwice, Poland \\ 2 University of Szczecin, Faculty of Geosciences, Geology and Palaeogeography Unit, Mickiewicza 18, 70-383 Szczecin, \\ Poland \\ 3 Pedagogical University of Cracow, Faculty of Geaography and Biology, Podchorążych 2, 30-084 Kraków, Poland \\ 4 University of Agriculture in Krakow, Faculty of Environmental Engineering and Land Surveying, Mickiewicza 21, 31-120 \\ Kraków, Poland \\ 5 University of Liège, Department of Geology, AGEs Argiles, Géochimie et Environnements sédimentaires, 14 Allée du 6 \\ août, Quartier Agora, B18, B-4000, Liège, Belgium
}

Pawełczyk, F., Bloom, K., Jucha, W., Michczyński, A., Okupny, D., Sikorski, J., Tomkowiak, J., Zając, E., Fagel, N., 2019. Reconstruction of atmospheric lead and heavy metal pollution in the Otrębowskie Brzegi peatland (S Poland). Geological Quarterly, 63 (3): 568-585, doi: 10.7306/gq.1487

We reconstruct palaeoenvironmental changes since the Late Holocene in the Orava-Nowy Targ Basin, with an emphasis on anthropogenic influence (Walker et al., 2018). This reconstruction employs multiproxy analyses of the Otrębowskie Brzeg poor fen. We combined radiocarbon and ${ }^{210} \mathrm{~Pb}$ dating with elemental geochemistry, stable lead isotopes, and palaeobotanical analyses. The core we investigated covers a period from $4200 \pm 100 \mathrm{BC}$ to the present, with a peat accumulation rate varying between 0.001 and $0.243 \mathrm{~cm} \mathrm{y}^{-1}$. Heavy metal concentrations, $\mathrm{Pb}$ isotopic ratios, and a palynological analysis revealed a significant impact of human activities in the past. The highest concentration and accumulation rate of $\mathrm{Pb}$, were found around $1950 \mathrm{AD}$. The ${ }^{206} \mathrm{~Pb} /{ }^{207} \mathrm{~Pb}$ quotient ranged between 1.168 and 1.223 , with average value around 1.198 . Most of the interpretation was based on $\mathrm{Pb}$ and its stable isotopes; however, other elements were also important indicators of natural and anthropogenic environmental changes. Our results revealed similarities between the geochemical composition of the peatland studied and other peatlands from the Orava-Nowy Targ Basin.

Key words: $\mathrm{Pb}$ isotopes, pollution, elemental record, human activity, ${ }^{14} \mathrm{C}$ and ${ }^{210} \mathrm{~Pb}$ dating, palynological analysis.

\section{INTRODUCTION}

Peat sediments, having accumulated for thousands of years, can provide important information about natural and anthropogenic environmental changes, e.g., dry and wet periods, changes in plant species, and human activities in the past (e.g., Mauquoy et al., 2002; Barber et al., 2003; Fiałkiewicz et al., 2008; Fiałkiewicz-Kozieł et al., 2014a). These sediments are also collectors of atmospheric particles of crustal and anthropogenic origin, among them pollutants. Records of trace elements in peatlands show periods of increased atmospheric pollution caused by human activities, such as coal mining and combustion, smelting, agriculture, and even urban traffic (e.g.,

\footnotetext{
* Corresponding author, e-mail: fatima.pawelczyk@polsı.pl
}

Received: April 8, 2019; accepted: June 14, 2019; first published online: September 18, 2019
Martínez-Cortizas et al., 2002; Coggins et al., 2006; Komárek et al., 2008; De Vleeschouwer et al., 2009; Fiałkiewicz-Kozieł et al., $2008,2011,2014 b, 2015)$. In particular, $\mathrm{Pb}$, which is highly toxic to people and the environment (Kabata-Pendias, 2011), is one of the most intensively investigated elements in recent years (e.g., Poller et al., 2001; Renson et al., 2008; De Vleeschouwer et al., 2010; Hansson et al., 2017). The isotopic ratios of stable lead isotopes: ${ }^{204} \mathrm{~Pb},{ }^{206} \mathrm{~Pb},{ }^{207} \mathrm{~Pb}$ and ${ }^{208} \mathrm{~Pb}$, can be used to decipher sources of $\mathrm{Pb}$ and their changes in the past (Shotyk et al., 1998). The lead isotope approach is a very helpful tool for environmental research, however, the partial mobility of lead isotopes in peatlands has been discussed by some authors. Also, other chemical elements are widely discussed in terms of their mobility (Novak and Pacherova, 2008; Śmieja-Król et al., 2010, 2015; Kabata-Pendias, 2011). This study is part of a larger work, including comparative analysis of two peatlands in Southern Poland - Otrębowskie Brzegi and Wolbrom. These peatlands differ in terms of location, lithology and anthropogenic impact (see Pawełczyk et al., 2017, 2018a, 2018b). In this study we investigated a core from the Otrębowskie Brzegi poor fen, located in the 
Orava-Nowy Targ Basin. It is an extensive, mid-mountainous basin in the Outer Western Carpathians, in southern Poland. In this area numerous peatlands were formed during the Holocene (Łajczak, 2009). This location makes them very interesting material for palaeoecological research, including for reconstructions of environmental changes and human activities. Early studies of the Orava-Nowy Targ Basin peatlands concerned changes in vegetation (Dyakowska, 1928; Koperowa 1962; Wójcikiewicz, 1979). Later geochemical analysis (Hołyńska et al., 1998) showed an anthropogenic impact. Subsequently peat sediments in this region have been studied in terms of human influence and degradation (e.g., Fiałkiewicz-Kozieł et al., 2011, 2014a, 2015, 2018; Michczyńska and Margielewski, 2016; Pawełczyk et al., 2018b). Other Carpathian peatlands (in Slovakia and Romania) have been studied as well. Attempts to reconstruct the history of the Carpathian region have been made by e.g. Rybniček and Rybničkova (1985, 2002), Rösch and Fischer (2000), Hájková et al. (2012) and Jamrichová et al. (2014).

The first phase of land utilization in Orava-Nowy Targ Basin took place in the Bronze and Iron ages and was connected with foraging, hunting and the first settlements in the river valleys (Ładygin, 1984; Rydlewski and Valde-Nowak, 1984). At the beginning of the 13th century more regular colonization began mostly connected with grazing. The 14 th century was a period of intensified settlement and agriculture in this region. At that time, the Czarny Dunajec, Odrowąż and Bańska settlements were established. Around the end of the 14th century, when Wallachian shepherds arrived in that region, the development of pastoralism began. The beginning of metallurgy in the area studied took place in the 15th century and was connected with first foundries in the Hucisko village, not far from Babia Góra mountain (Jost, 2004). From that time, mining and metallurgy was the main factor of settlement development in the Carpathian foreland (Solecki, 1977). In the Tatra Mountains iron, silver and copper ores were extracted. In 19th century, many steelworks processed the Tatra flysch rocks, in the Orava-Nowy Targ Basin and its vicinity, i.e. in Stryszawa, Maków, Podczerwone, Huciska. Kośne Hamry, Kuźnice, Jaworzyna Spiska and so on (Fig. 1C; Jost, 1962, 2004).

The Carpathian region is an area with a long history of human presence as regards mining and metallurgy (Borcoş and Udubaşa, 2012; Longman and Veres, 2016; Longman et al. 2016, 2018). While the characteristics of past emission sources and effects of heavy metal pollution are well known in Western Europe, there is a deficit of such studies in Eastern Europe. This study aims to partially fill this gap, by reconstruction of the anthropogenic impact on the Otrębowskie Brzegi peatland, along with the course of its natural changes in the past. We performed geochemical analysis, with special emphasis on heavy metal concentrations and lead isotopic composition. These data, as well as botanical and palynological analyses, were compiled with ${ }^{14} \mathrm{C}$ and ${ }^{210} \mathrm{~Pb}$ chronology. As a result, we reconstructed the history of the peatland from $\sim 4200$ BC to the present.

\section{MATERIAL AND METHODS}

\section{STUDY SITE, CORING AND SAMPLING}

Otrębowskie Brzegi is a poor fen, which means that the sources of water and nutrients are mainly precipitation, with secondary contributions from groundwater and flowing waters. The peatland is located in the western part of the Orava-Nowy Targ Basin, near the village of Jabłonka (Fig. 1A), at $\sim 1 \mathrm{~km}$ from the Polish-Slovak border (Fig. 1B, C). The peatland is situated close to the mountains. The massif of Babia Góra is about $10 \mathrm{~km} \mathrm{NW}$ from the peatland and the Tatra Mountains are about $30 \mathrm{~km}$ to the south, thus the area is partially protected from pollution coming from the main Polish mining areas (Olkusz, Silesia) and central urban areas (Katowice, Kraków). However, the Otrębowskie Brzegi peatland may receive some pollution from the west, from the Orava region.

The peatland is about $600 \mathrm{~m}$ long and $500 \mathrm{~m}$ wide -42 ha (Lipka and Zając, 2014), situated $620 \mathrm{~m}$ above sea level and gently sloping toward the south (Fig. 1B, C). The climate of the Orava-Nowy Targ Basin is slightly more severe than the average conditions in Poland, with mean annual temperature about $5.5^{\circ} \mathrm{C}$ and mean annual precipitation varying around $800 \mathrm{~mm}$ (Olszewski, 1988). Westerly and southwesterly winds prevail. The Otrębowskie Brzegi peatland has been described by several authors: the development conditions by Łajczak (2009, 2013), a stratigraphic transect by Lipka and Zając (2014) and there have been some analyses of mercury content (Sławińska et al., 2018). However, the chronology of Otrębowskie Brzegi, its palaeobotanical history, major and trace element concentrations and isotope geochemistry have not been investigated.

In September 2016 the Otrębowskie Brzegi peatland was probed using a peat corer to measure the peat thickness. An interpolated model was developed by using the kriging interpolation method on 71 drillings (Fig. 2). The average thickness of peat is about $1.63 \mathrm{~m}$; the thickest layer of peat occurs north of the center of the study area. In the southern part of the peatland, the thickness of the peat layer gradually decreases toward the meandering channel of the Czarna Orawa River. A $3.21 \mathrm{~m}$ long peat core (JB-1) was taken using an Instorf corer at $\mathrm{N} 49^{\circ} 27.771^{\prime} \mathrm{E} 19^{\circ} 39.278^{\prime}$. The core was transported to the laboratory, divided into samples and stored prior to dating and other analyses.

\section{CHRONOLOGY}

The chronology for Otrębowskie Brzegi was constructed by merging radiocarbon and ${ }^{210} \mathrm{~Pb}$ dates. For radiocarbon dating, 13 samples were selected: ten were prepared following the procedure of Skripkin and Kovaliukh, (1998) and dated using the liquid scintillation technique (LSC) on a Quantulus $1220^{\mathrm{TM}}$ spectrometer in the Gliwice Radiocarbon Laboratory (Pawlyta et al., 1998). The other three samples were dated using acceleration mass spectrometry (AMS) because of the smaller amount of peat in the upper part of the core. The samples were prepared in accordance with the protocol by Piotrowska (2013). The upper $20 \mathrm{~cm}$ of the cores were also dated by measuring ${ }^{210} \mathrm{~Pb}$ activity using alpha spectrometry (Sikorski and Bluszcz, 2008). Details of preparation and measurement methods for both radiocarbon and ${ }^{210} \mathrm{~Pb}$ dating are described in Pawełczyk et al. (2017). In order to build the final age-depth model, ${ }^{14} \mathrm{C}$ and ${ }^{210} \mathrm{~Pb}$ data were calibrated and analysed using $\mathrm{OxCal}$ software (Bronk Ramsey and Lee, 2013) with the calibration data set of the IntCal13 (Reimer et al., 2013) and Bomb13 NH1 calibration curves (Hua et al., 2013). The resulting age-depth model was used to calculate the $\mathrm{Pb}$ accumulation rate $\left(A R\right.$ in $\left.\mathrm{mg} \mathrm{m}^{-2} \mathrm{y}^{-1}\right)$ according to the formula:

$$
A R=c \times b \times a r \times 10
$$

where: $c$ - the concentration of the element measured in $\mathrm{mg} \mathrm{kg}^{-1}, b$ - the bulk density of peat in $\mathrm{g} \mathrm{cm}^{-3}$; ar-accumulation rate of peat in $\mathrm{cm} \mathrm{y^{-1 }}$.

A peat core was divided into samples, intended for different analyses, and dried directly after coring. This procedure caused 


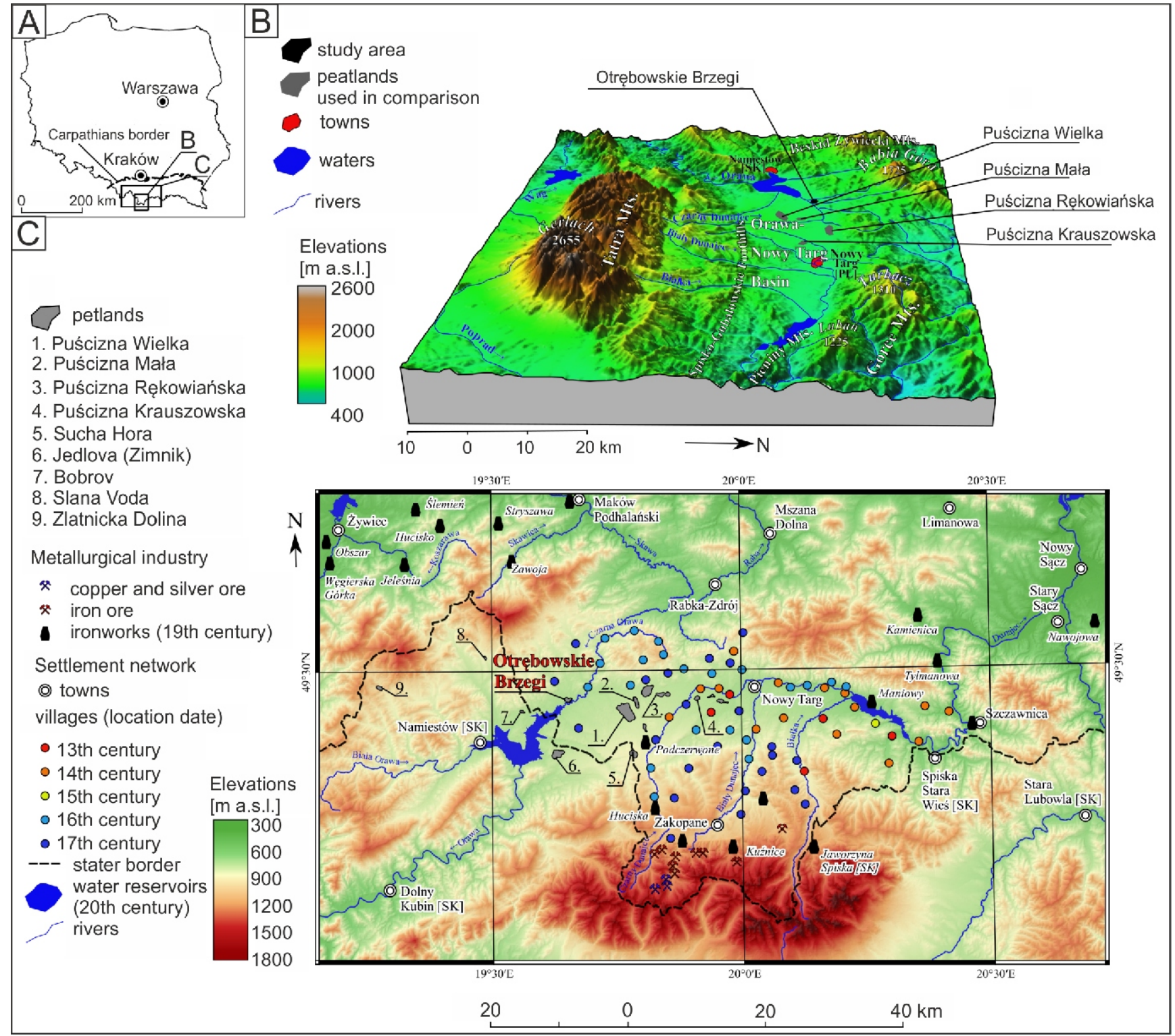

Fig. 1A-C - site location (villages location dates after Jost and Paulo, 1985; Jost, 2004)

a lack of fresh peat material, so bulk density was estimated using the data from IInicki (1967). The values of density were in the range of 0.08 to $0.185 \mathrm{~g} \mathrm{~cm}^{-3}$.

\section{PALAEOBOTANICAL ANALYSES}

BOTANICAL COMPOSITION

The degree of decomposition and the types of peat were recorded in 12 samples from different depths, using standard methodology (Maciak and Liwski, 1996; Maksimow, 1965; Myślińska, 2001; Tobolski, 2000). Microscopic analysis (PN-G-04595, 1997) was used to determine botanical composition, using comparative samples and literature (Kac et al., 1977; Tobolski, 2000; Mauquoy and Van Geel, 2007). The samples were washed on a $0.2 \mathrm{~mm}$ sieve and each sample was divided into 3 slides, which were analysed under a microscope at magnification 100-400x. Typological units of peat were defined using the genetic classification of Tołpa et al. (1967). The types of gyttja were defined using the classification of Ilnicki (2002). The analyses were performed at the Department of Land Reclamation and Environmental Development, at the University of Agriculture in Kraków.

\section{POLLEN ANALYSIS}

Twenty-nine $1 \mathrm{~cm}^{3}$ samples from JB-1 were taken at resolutions of $2 \mathrm{~cm}$ (from the top to $35 \mathrm{~cm}$ depth) and $10 \mathrm{~cm}$ (from 35 to $315 \mathrm{~cm}$ depth). The material was macerated in HF for 10 days, then washed in $10 \% \mathrm{HCl}$ and distilled water. Next, the samples were boiled in $10 \% \mathrm{KOH}$ solution in a water bath and then treated with acetolysis, using standard methodology (Fægri and Iversen, 1989). Two Lycopodium tablets produced by the Department of Quaternary Geology, the University in Lund (Batch No. 483216) were added to the sediment in order to enable the pollen concentration to be calculated (Stockmarr, 1971). The samples were not subjected to a dyeing process.

Microscopes (Nikon Eclipse E200 and Zeiss Axio Image A2 with Nomarski's contrast) were used at $400 \times$ to count at least 1000 arboreal pollen grains. Non-arboreal pollen and non-pol- 


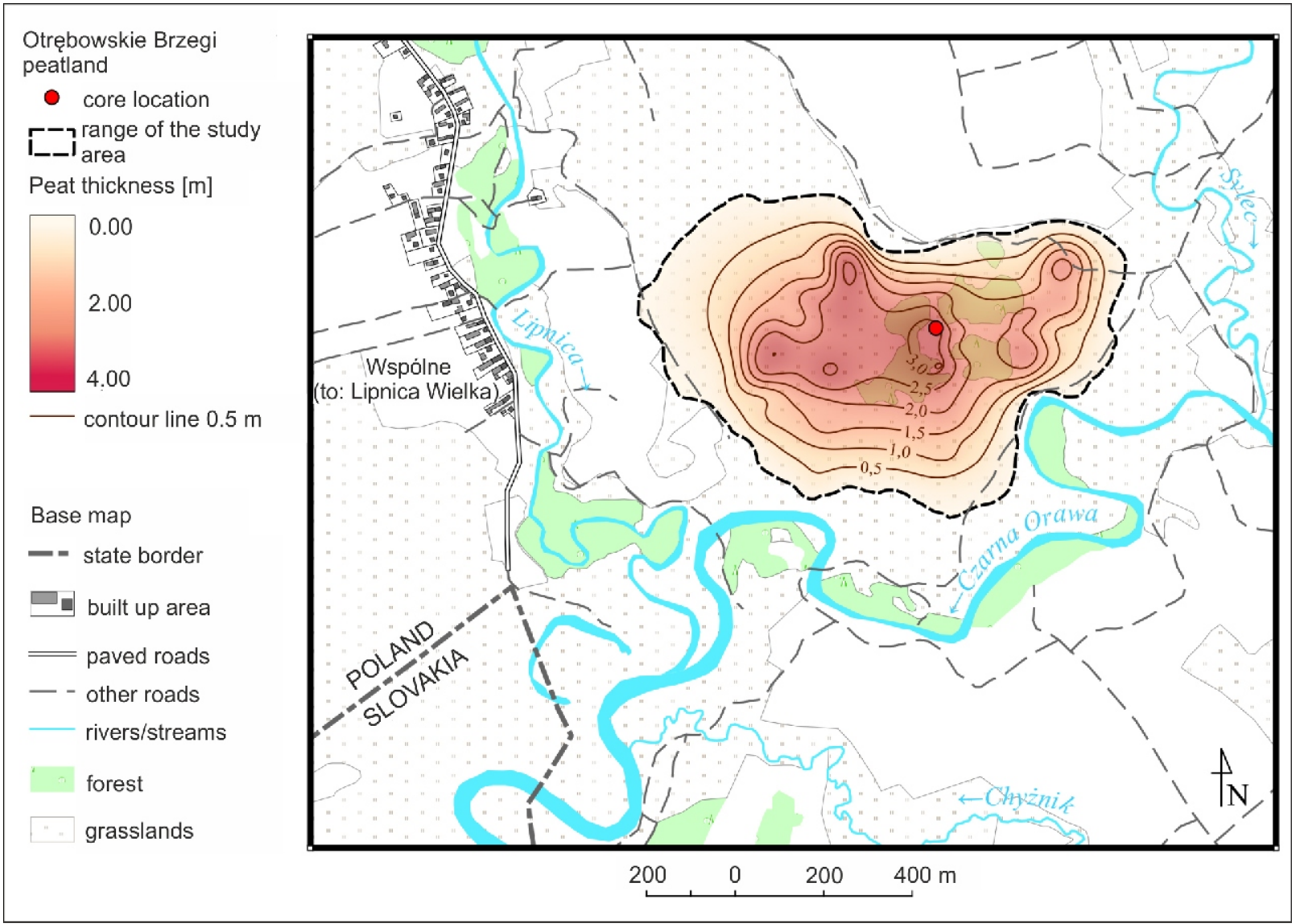

Fig. 2. The thickness of the Otrębowskie Brzegi peatland

len palynomorphs - mostly fungal spores and microscopic charcoal particles - were also counted. Sporomorphs were counted on the whole surface of the slide. The collection of reference slides at the Department of Geology and Palaeogeography of Szczecin University were used to identify the sporomorphs. Reference books and illustrated handbooks were also used (e.g., Fægri and Iversen, 1989; Moore et al. 1991; Beug, 2004). The nomenclature of palynological taxa was adopted according to the Polish Palynological Database.

The pollen analysis results are presented in the form of percentage diagrams developed in POLPAL 2004 software, ver. 2011.11 (Walanus and Nalepka, 2004). The basis of the percentage calculation is the sum of AP + NAP; AP comprises pollen grains of all trees and shrubs, while NAP includes sporomorphs of terrestrial herbs, i.e. graminides. In general, pollen of limnophytes and telmatophytes are not included in the calculated sum. Palynological analysis was performed at the Geology and Palaeogeography Unit in the Faculty of Geosciences at the University of Szczecin.

\section{GEOCHEMICAL ANALYSIS}

\section{ELEMENTAL CONCENTRATIONS}

The concentrations of selected major and trace elements ( $\mathrm{Na}, \mathrm{K}, \mathrm{Ca}, \mathrm{Mg}, \mathrm{Fe}, \mathrm{Mn}, \mathrm{Cu}, \mathrm{Zn}, \mathrm{Pb}, \mathrm{Ni}$, and $\mathrm{Cr}$ ) were measured in 48 peat samples. Every sample consisted of about $1 \mathrm{~g}$ of manually ground peat. The samples were homogenized and thoroughly dried at $105^{\circ} \mathrm{C}$. Next, the samples were combusted at $550^{\circ} \mathrm{C}$ for 5 hours to remove organic matter, and then digested in $8 \mathrm{ml}$ of $65 \% \mathrm{HNO}_{3}, 2 \mathrm{ml}$ of $10 \% \mathrm{HCl}$, and $2 \mathrm{ml}$ of $30 \%$
$\mathrm{H}_{2} \mathrm{O}_{2}$ in individual PTFE vials. Afterwards they were put into a mineralizer for 1 hour. After mineralizing, the samples were transferred into polypropylene beakers and diluted to $50 \mathrm{ml}$ with de-ionized water. The concentrations of major and trace elements were measured using atomic absorption spectrometry (AAS). Whole chemical preparation and measurements were performed in the Geochemical Laboratory at the Faculty of Geosciences of the University of Szczecin, Poland. The routine methodology of the laboratory was used. The geochemical zones from the JB-1 core were distinguished using multivariate statistical analysis with cluster analysis from the PAST software (Hammer et al., 2001).

\section{$\mathrm{Pb}$ ISOTOPES}

Thirty samples from JB-1 were selected to measure their ratios of stable lead isotopes. The samples were dried, homogenized, and ground in an automatic agate mortar. After drying $\left(105^{\circ} \mathrm{C}, 12 \mathrm{~h}\right)$ the samples were combusted $\left(550^{\circ} \mathrm{C}, 5 \mathrm{~h}\right)$, dissolved in a mixture of $1 \mathrm{ml}$ of $14 \mathrm{~N} \mathrm{HNO}_{3}$ and $4 \mathrm{ml}$ of $22 \mathrm{~N} \mathrm{HF}$ at $125^{\circ} \mathrm{C}$ for $48 \mathrm{~h}$ in a laminar flow clean air cabinet. After drying, the samples were dissolved again in $2 \mathrm{ml}$ of $6 \mathrm{~N} \mathrm{HCl}$ and $2 \mathrm{ml}$ of $14 \mathrm{~N}$ $\mathrm{HNO}_{3}$ at $125^{\circ} \mathrm{C}$ to evaporation. The separation of $\mathrm{Pb}$, using exchange micro-columns filled with pre-conditioned AG1-X8 anionic resin, was performed according to the protocol of Weis et al. (2005). The chemical preparation was carried out at the Department of Geology of the University of Liège in Belgium. $\mathrm{Pb}$ isotopic measurements were performed using multi-collector inductively coupled plasma mass spectrometry, $\mathrm{Nu}$ plasma (MC-ICP-MS) at the Department of Earth and Environmental Sciences at the Free University of Brussels, Belgium. 
Results of ${ }^{14} \mathrm{C}$ analysis, ${ }^{14} \mathrm{C}$ data were used to construction of an age-depth model, using OxCal software (Bronk Ramsey and Lee, 2013) with the calibration data set of IntCal13 (Reimer et al., 2013) and Bomb13 NH1 calibration curves (Hua et al., 2013)

\begin{tabular}{|l|c|c|c|c|}
\hline Lab code & $\begin{array}{c}\text { Depth } \\
{[\mathrm{cm}]}\end{array}$ & $\begin{array}{c}\text { Conventional }{ }^{14} \mathrm{C} \\
\text { age/radioactivity } \\
\text { [BP/ pMC] }\end{array}$ & $\begin{array}{c}\text { Modelled age range 68.2\% } \\
\text { [cal BC/AD] }\end{array}$ & $\begin{array}{c}\text { Modelled age range } \\
95.4 \% \text { [cal BC/AD] }\end{array}$ \\
\hline GdA-5222 & 9 & $136.81 \pm 0.36$ & $1958-1964 \mathrm{AD}$ & $\begin{array}{c}1958-1958 \mathrm{AD}(91.4 \%) \\
1974-1977 \mathrm{AD}(4.0 \%)\end{array}$ \\
\hline GdA-5223 & 19 & $1370 \pm 30$ & $635-670 \mathrm{AD}$ & $605-680 \mathrm{AD}$ \\
\hline GdA-5224 & 27 & $1615 \pm 30$ & $505-540 \mathrm{AD}$ & $485-550 \mathrm{AD}$ \\
\hline GdS-3479 & 37 & $1510 \pm 55$ & $425-475 \mathrm{AD}$ & $410-500 \mathrm{AD}$ \\
\hline GdS-3562 & 53 & $1650 \pm 50$ & $\begin{array}{c}255-300 \mathrm{AD}(37.0 \%) \\
325-365 \mathrm{AD}(31.2 \%)\end{array}$ & $245-395 \mathrm{AD}$ \\
\hline GdS-3563 & 73 & $1895 \pm 50$ & $20-115 \mathrm{AD}$ & 40 BC-145 AD \\
\hline GdS-3530 & 98 & $2510 \pm 55$ & $460-405 \mathrm{BC}$ & $520-395 \mathrm{BC}$ \\
\hline GdS-3569 & 125 & $2490 \pm 55$ & $760-640 \mathrm{BC}$ & $790-590 \mathrm{BC}$ \\
\hline GdS-3480 & 164 & $2935 \pm 60$ & $1120-1015 \mathrm{BC}$ & $1180-970 \mathrm{BC}$ \\
\hline GdS-3570 & 189 & $3045 \pm 50$ & $1320-1230 \mathrm{BC}$ & $1380-1195 \mathrm{BC}$ \\
\hline GdS-3526 & 213 & $3150 \pm 50$ & $1505-1430 \mathrm{BC}$ & $\begin{array}{c}1605-1580 \mathrm{BC}(1.8 \%) \\
1545-1385 \mathrm{BC}(93.6 \%)\end{array}$ \\
\hline GdS-3531 & 254 & $3570 \pm 55$ & $\begin{array}{c}1985-1870 \mathrm{BC}(59.6 \%) \\
1845-1825 \mathrm{BC}(4.4 \%)\end{array}$ & $2035-1770 \mathrm{BC}$ \\
\hline GdS-3396 & 288 & $5385 \pm 90$ & $\begin{array}{c}4335-4220 \mathrm{BC}(36.3 \%) \\
4210-4160 \mathrm{BC}(13.7 \%) \\
4135-4065 \mathrm{BC}(18.2 \%)\end{array}$ & $4370-3985 \mathrm{BC}$ \\
\hline
\end{tabular}

lab codes GdA - AMS method, lab codes GdS - LSC method

\section{RESULTS}

AGE-DEPTH MODEL

The results of radiocarbon dating are shown in Table 1. The age-depth model derived is shown in Figure 3. The chronology of the upper $16.5 \mathrm{~cm}$ of the core is very well-defined by nine ${ }^{210} \mathrm{~Pb}$ dates and one ${ }^{14} \mathrm{C}$ date. It covers a time span from $\sim 1890 \mathrm{AD}$ to the present. The ${ }^{14} \mathrm{C}$ date from a depth of $9 \mathrm{~cm}$ is in agreement with ${ }^{210} \mathrm{~Pb}$ dates. The first ${ }^{14} \mathrm{C}$ date below that part of the chronology (from $19 \mathrm{~cm}$ depth) is much older (605-680 AD; $95.4 \%$ confidence interval) than the last ${ }^{210} \mathrm{~Pb}$ date (from $16.5 \mathrm{~cm}$ ). It shows that a hiatus occurs at a depth of $17-18 \mathrm{~cm}$. The remaining dates, down to the bottom of the peat profile, located at $285 \mathrm{~cm}$ depth and dated at $2250 \mathrm{BC} \pm 120 \mathrm{yrs}$, present an undisturbed stratigraphic order. The last sample at $288 \mathrm{~cm}$ (dated at 4370-3985 BC) is a gyttja sample older than the bottom of the peat profile. This difference may be caused by an aging effect. A reservoir effect is highly probable because the bottom sample is a lake sediment-organic gyttja (see Table 2); interpretation of the bottom part should with caution. The total agreement index of the model is almost $60 \%$, sufficient to consider the model reliable.

\section{PALAEOBOTANICAL DATA}

The analysis of botanical macrofossils demonstrates the occurrence of numerous Carex and Sphagnum remains (Ta- ble 2). This botanical composition is characteristic of poor fens. The lower parts of the JB-1 profile $(220-280 \mathrm{~cm})$ contain Alnus remains, characteristic of fen peat. The lowest parts of the profile $(286-293 \mathrm{~cm})$ consist of organic and clay gyttja, which indicates a lacustrine origin of the Otrębowskie Brzegi peatland. A part of the peatland, from which the JB-1 core was taken, was classified as a Rheic Hemic Histosol (Dystric), according to international soil classification (WRB). The palynological diagram (Fig. 4) reveals the main taxa in the Otrębowskie Brzegi peatland. It shows changing trends in the composition of AP and NAP. Four local pollen assemblage zones (LPAZ) are characterized in Table 3.

\section{GEOCHEMICAL ANALYSIS}

The geochemical analysis showed variability of both the elements measured and geochemical indices (Fig. 5). The highest concentration of $\mathrm{Pb}$ is also reflected in the calculated accumulation rate for this element (Fig. 6).

Using the PAST software (Hammer et al., 2001) three zones with additional sub-zones were distinguished in the peat profile:

- GZ1 (321-212 cm); from 4370-3985 BC to 1510-1325 BC. This zone was divided into two sub-zones:

a. $321-279 \mathrm{~cm}$; from $4370-3985 \mathrm{BC}$ to $2430-1970 \mathrm{BC}$; this zone covers gyttja deposits and the lowest part of the peat profile. At the bottom of this zone the content of organic matter (OM) reaches its lowest value (about 
OxCal v4.3.2 Bronk Ramsey (2017); r:5 IntCal13 atmospheric curve (Reimer et al., 2013)

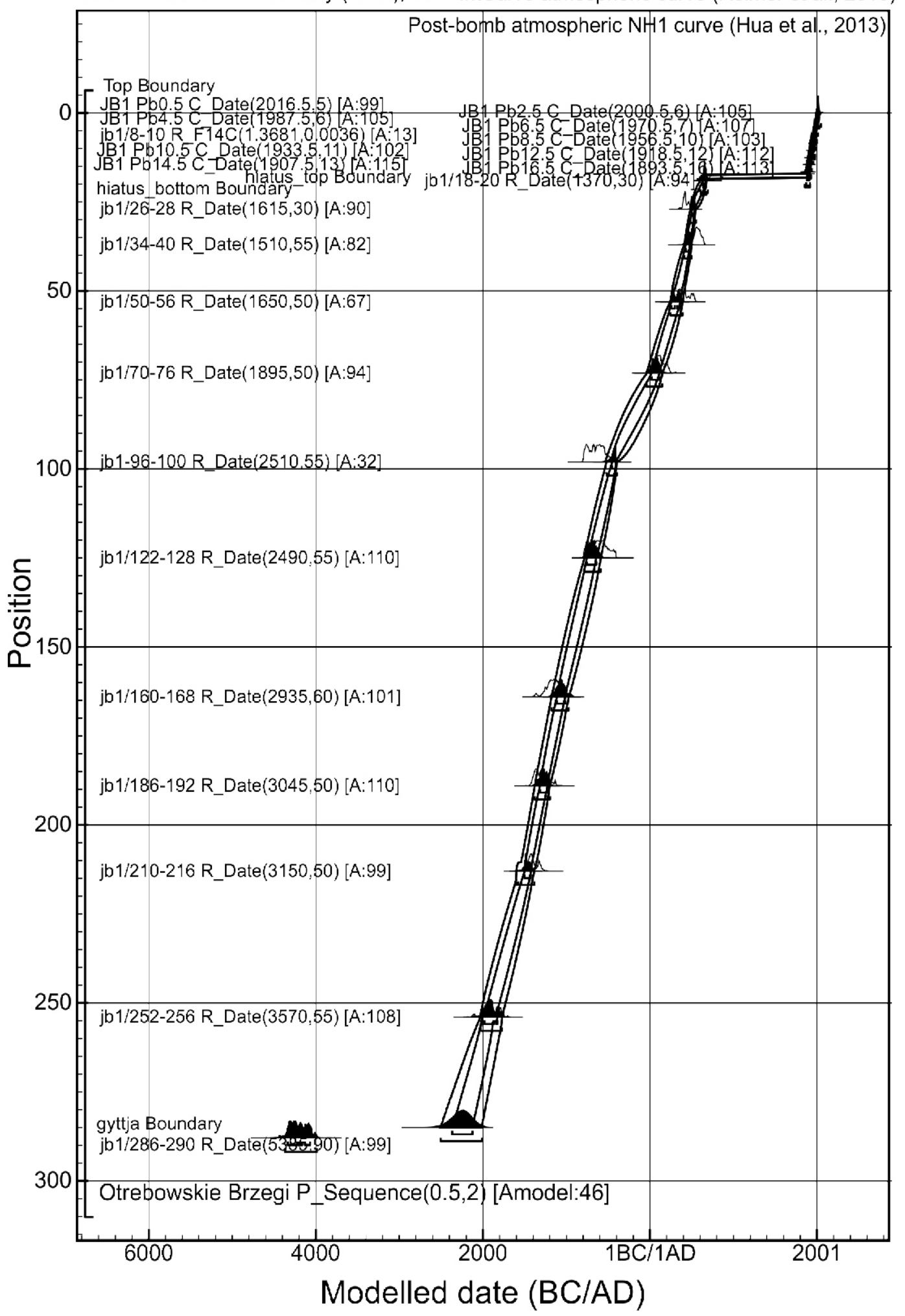

Fig. 3. Age-depth model of the JB-1 core 
Table 2

Otrębowskie Brzegi - results of botanical analysis

\begin{tabular}{|c|c|c|c|c|}
\hline \multirow{2}{*}{ Depth [cm] } & \multicolumn{2}{|l|}{ Botanical composition } & \multirow{2}{*}{$\begin{array}{l}\text { Peat species } \\
\text { Type of gyttja }\end{array}$} & \multirow{2}{*}{$\mathrm{D}[\%]$} \\
\hline & Species & {$[\%]$} & & \\
\hline \multirow{9}{*}{$36-46$} & Sphagnum sp. & 20 & \multirow{9}{*}{ Sphagno-Cariceti } & \multirow{9}{*}{35} \\
\hline & Carex lasiocarpa & \multirow{3}{*}{45} & & \\
\hline & Carex rostrata & & & \\
\hline & Carex sp.div. & & & \\
\hline & Eriophorum angustifolium & 5 & & \\
\hline & Rhynchospora alba & + & & \\
\hline & Pterodiophyta sp. & 5 & & \\
\hline & Pinus sylvestris & 5 & & \\
\hline & Unidentified & 5 & & \\
\hline \multirow{11}{*}{$70-80$} & Sphagnum fallax & \multirow{2}{*}{35} & \multirow{11}{*}{ Sphagno-Cariceti } & \multirow{11}{*}{25} \\
\hline & Sphagnum sp. s. Cuspidata & & & \\
\hline & Carex lasiocarpa & \multirow{3}{*}{25} & & \\
\hline & Carex rostrata & & & \\
\hline & Carex sp. div. & & & \\
\hline & Eriophorum vaginatum & 15 & & \\
\hline & Rhynchospora alba & 5 & & \\
\hline & Scheuchzeria palustris & + & & \\
\hline & Menyanthes trifoliata & 10 & & \\
\hline & Pinus sylvestris & 5 & & \\
\hline & Unidentified & 5 & & \\
\hline \multirow{9}{*}{$106-116$} & Sphagnum sp. & 20 & \multirow{9}{*}{ Sphagno-Cariceti } & \multirow{9}{*}{35} \\
\hline & Carex lasiocarpa & \multirow{3}{*}{35} & & \\
\hline & Carex rostrata & & & \\
\hline & Carex sp. & & & \\
\hline & Eriophorum vaginatum & 15 & & \\
\hline & Menyanthes trifoliata & 10 & & \\
\hline & Andromeda polifoila & \multirow{2}{*}{15} & & \\
\hline & Oxyccocus palustris & & & \\
\hline & Unidentified & 5 & & \\
\hline \multirow{8}{*}{$130-140$} & Sphagnum sp. div. & 30 & \multirow{8}{*}{ Sphagno-Cariceti } & \multirow{8}{*}{30} \\
\hline & Carex lasiocarpa & 25 & & \\
\hline & Carex rostrata & 00 & & \\
\hline & Rhynchospora alba & 5 & & \\
\hline & Menyanthes trifoliata & 15 & & \\
\hline & Ericaceae sp. (bark) & 5 & & \\
\hline & Pinus sylvestris & 5 & & \\
\hline & Unidentified & 5 & & \\
\hline \multirow{9}{*}{$150-160$} & Sphagnum sp. div. & 40 & \multirow{9}{*}{ Sphagno-Cariceti } & \\
\hline & Carex rostrata & 20 & & \\
\hline & Eriophorum vaginatum & 5 & & \\
\hline & Rhynchospora alba & 5 & & \\
\hline & Menyanthes trifoliata & 10 & & 20 \\
\hline & Comarum palustre & 5 & & \\
\hline & Andromeda polifoila? & 10 & & \\
\hline & Ericaceae sp. & 10 & & \\
\hline & Unidentified & 5 & & \\
\hline
\end{tabular}

\begin{tabular}{|c|c|c|c|c|}
\hline \multirow{10}{*}{$174-184$} & Sphagnum sp. div. & 35 & \multirow{10}{*}{ Sphagno-Cariceti } & \multirow{10}{*}{30} \\
\hline & Carex rostrata & \multirow{2}{*}{30} & & \\
\hline & Carex sp. & & & \\
\hline & Eriophorum vaginatum & 10 & & \\
\hline & Rhynchospora alba & + & & \\
\hline & Menyanthes trifoliata & 10 & & \\
\hline & Oxyccocus palustris & \multirow{2}{*}{10} & & \\
\hline & Ericaceae sp. & & & \\
\hline & Pinus sylvestris & + & & \\
\hline & Unidentified & 5 & & \\
\hline \multirow{10}{*}{ 190-200 } & Sphagnum sp. div. & 35 & \multirow{10}{*}{ Sphagno-Cariceti } & \multirow{10}{*}{25} \\
\hline & Aulacomium palustre & + & & \\
\hline & Carex sp. & 35 & & \\
\hline & Eriophorum vaginatum & 10 & & \\
\hline & Scheuchzeria palustris & + & & \\
\hline & Menyanthes trifoliata & 10 & & \\
\hline & Oxyccocus palustris & \multirow{2}{*}{5} & & \\
\hline & Ericaceae sp. div. & & & \\
\hline & Pinus sylvestris & + & & \\
\hline & Unidentified & 5 & & \\
\hline \multirow{16}{*}{$220-230$} & Sphagnum fallax & 15 & \multirow{16}{*}{ Alneti } & \multirow{16}{*}{40} \\
\hline & Bryales sp. div. & 20 & & \\
\hline & Carex rostrata & \multirow{4}{*}{15} & & \\
\hline & Carex fusca & & & \\
\hline & Carex riparia & & & \\
\hline & Carex sp. & & & \\
\hline & Eriophorum sp. & + & & \\
\hline & Scheuchzeria palustris & + & & \\
\hline & Menyanthes trifoliata & 5 & & \\
\hline & Phragmites australis & + & & \\
\hline & Equisetum fluviatile? & + & & \\
\hline & Alnus glutinosa & \multirow{4}{*}{40} & & \\
\hline & Salix sp. (bark) & & & \\
\hline & Picea sp. (bark) & & & \\
\hline & deciduous wood & & & \\
\hline & Unidentified & 5 & & \\
\hline \multirow{10}{*}{$270-280$} & Sphagnum fallax? & + & \multirow{10}{*}{ Alneti } & \multirow{10}{*}{50} \\
\hline & Bryales sp. & 5 & & \\
\hline & Equisetum fluviatile? & + & & \\
\hline & Alnus glutinosa & + & & \\
\hline & Salix sp. (bark) & 35 & & \\
\hline & Frangula alnus & 10 & & \\
\hline & Pinus? & 15 & & \\
\hline & Picea sp. (bark) & 20 & & \\
\hline & $\begin{array}{c}\text { deciduous and coniferous } \\
\text { wood }\end{array}$ & 5 & & \\
\hline & Unidentified & 10 & & \\
\hline $286-290$ & & & Organic gyttja & \\
\hline 290292 & & & Clay gyttja & \\
\hline $296-322$ & & & Mineral substrate & \\
\hline
\end{tabular}

Peat species were classified according to Tołpa et al. (1967) and gyttja as per Ilnicki (2002); degree of decomposition (D) was determined according to Polish Standard (PN-G-04595, 1997) 


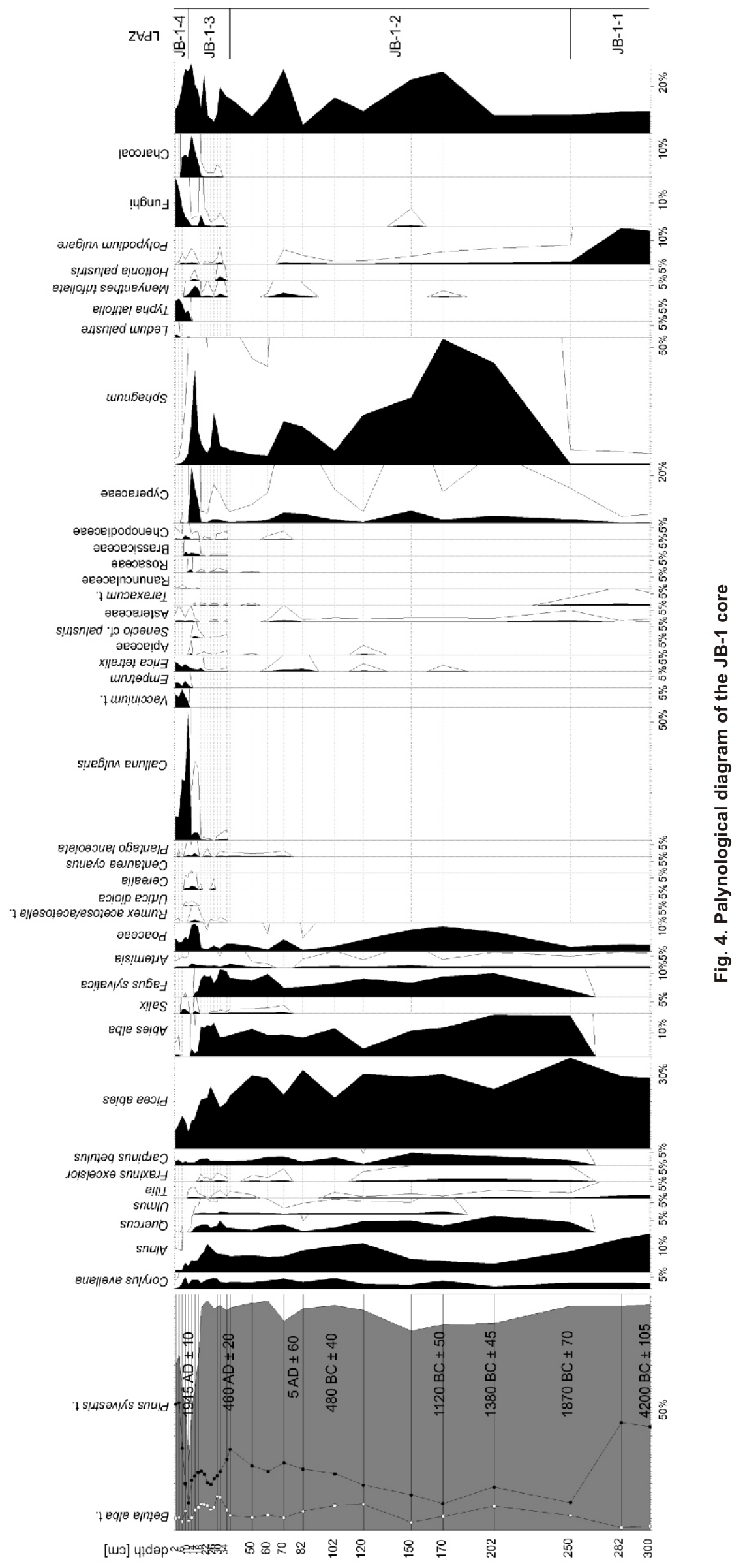


Characteristics of local pollen assemblage zones (LPAZ)

\begin{tabular}{|c|c|c|c|c|}
\hline $\begin{array}{l}\text { Local } \\
\text { PAZ }\end{array}$ & Name of PAZ & $\begin{array}{l}\text { Depth } \\
{[\mathrm{cm}]}\end{array}$ & $\begin{array}{c}\text { Approx ages } \\
\text { BC/AD }\end{array}$ & Description of pollen spectra \\
\hline JB-1-1 & Pinus-Alnus & 300 & $4200 \mathrm{BC}$ & $\begin{array}{c}\text { Curves of Pinus relatively stable with high value } 45 \% \\
\text { Betula increase; Corylus and Tilia stable represented by low values; } \\
\text { Alnus decrease (mean. 14\%, max. 16\%); Poaceae max 3\%, Artemisia } \\
\text { less than 1\%; } \\
\text { High value of Polypodiaceae curve (14\%); } \\
\text { JB-1-1/JB-1-2 limit Pinus and decrease, Picea increase }\end{array}$ \\
\hline JB-1-2 & Picea-Carpinus-Poaceae & 250 & $1870 \mathrm{BC}$ & $\begin{array}{c}\text { Quercus, Fraxinus, Carpinus, Abies, Fagus curves appears; } \\
\text { High percentage of Pinus (mean. } 11 \% \text {, max. } 28 \%) \text {; Betula increase } \\
\text { (max. 11\%); Corylus stable with value between } 1 \text { and } 4 \% ; \\
\text { Picea curve remains high ( } 38 \% \text { ) similar to Poaceae (10\%); Carpinus is } \\
\text { represented by high values (5\%); } \\
\text { Sphagnum curve rising and later dominates in diagram similar to } \\
\text { Cyperaceae; } \\
\text { Plantago lanceolata curve appears; } \\
\text { JB-1-2/JB-1-3 limit Betula and Fagus increase, Pinus decrease }\end{array}$ \\
\hline JB-1-3 & Betula-Fagus-Abies & 36 & $460 \mathrm{AD}$ & $\begin{array}{c}\text { Pinus decrease, Betula curve rises to } 15 \% ; \\
\text { Increasing values of Corylus and Alnus; } \\
\text { (nImus and Tilia are represented in low percentage; relatively significant } \\
\text { proportion of Abies; } \\
\text { Picea values between } 11 \text { and } 26 \% ; \text { high percentages of Poaceae } \\
(11 \%) ; \\
\text { Curves of crops, cultivated plants and field weeds appear; } \\
\text { Amount of charcoal particles rise max. } 26 \% ; \\
\text { Curves of Telmatophytes and Limnophytes appear, with maximum of } \\
\text { Menyantes trifoliata (5\%); } \\
\text { JB-1-3/JB-1-4 limit increase of Pinus and Picea }\end{array}$ \\
\hline JB-1-4 & Pinus-Picea-Calluna & 10 & 1945 AD & $\begin{array}{l}\text { Dramatic increase of Pinus (max. } 54 \% \text {; } \\
\text { curve fluctuations of Betula, Corylus and Alnus; } \\
\text { Picea rise to } 13 \% \text {; continuous curve of Atremisia; } \\
\text { Sharp increase of Calluna with max. } 55 \% \text {; } \\
\text { Typha is represented at high percentage } 9 \% \text {; } \\
\text { Poaceae pollen values between } 3 \text { and } 6 \% \text {. }\end{array}$ \\
\hline
\end{tabular}

$2 \%$ ), then increases up to about $70 \% . \mathrm{K}, \mathrm{Mg}$, Fe and $\mathrm{Cr}$ reach their highest values $(5131.6,7458.4,18,182.6$ and $38.2 \mathrm{\mu g} \mathrm{g}^{-1}$, respectively). The content of $\mathrm{Ca}$ is low at the bottom of the zone $\left(133.2 \mathrm{\mu g} \mathrm{g}^{-1}\right)$, then increases rapidly up to over $11,000 \mathrm{\mu g} \mathrm{g}^{-1}$ at the sub-zone boundary. In this sub-zone the $\mathrm{Na} / \mathrm{K}$ ratio increases rapidly and reaches its highest value at $285 \mathrm{~cm}$ (1.6).

b. $279-212 \mathrm{~cm}$; from $2430-1970 \mathrm{BC}$ to $1510-1325 \mathrm{BC}$; in this sub-zone the content of OM increases from $\sim 70 \%$ to $93 \%$. The concentrations of all measured elements decrease.

- GZ2 (212-6 cm); from 1510-1325 BC to 1960-1990 $A D$, was divided into three sub-zones:

a. $212-105 \mathrm{~cm}$; from $1510-1325 \mathrm{BC}$ to $465-540 \mathrm{AD}$; this sub-zone is characterized by a high concentration of OM $(>93 \%)$. Concentrations of $\mathrm{Ca}, \mathrm{Fe}$, and $\mathrm{Mn}$ decrease, while concentrations of heavy metals $(\mathrm{Cu}, \mathrm{Zn}$, $\mathrm{Pb}$ and $\mathrm{Cr}$ ) slightly increase. There is a distinct peak of $\mathrm{Cu}$ at $129 \mathrm{~cm}\left(52 \mathrm{\mu g} \mathrm{g}^{-1}\right)$. The Cu/Zn ratio reaches its highest value in this zone (6.3).

b. $105-49 \mathrm{~cm}$; from $465-540 \mathrm{AD}$ to $275-425 \mathrm{AD}$; in this sub-zone the concentration of $\mathrm{OM}$ is high and rather stable - only small variations, between 95 and $97 \%$, occur. The concentrations of $\mathrm{Cu}, \mathrm{Zn}$, and $\mathrm{Pb}$ still increase, while the contents of $\mathrm{Ca}, \mathrm{Fe}$, and $\mathrm{Mn}$ decrease slightly.

c. $49-6 \mathrm{~cm}$; from $275-425$ AD to $1965-1985$ AD - the deposits of this sub-zone are characterized by decreasing concentrations of OM (down to $90 \%$ ). The concentrations of $\mathrm{Na}, \mathrm{K}, \mathrm{Ca}, \mathrm{Mg}, \mathrm{Fe}, \mathrm{Zn}$, and $\mathrm{Pb}$ increase and $\mathrm{Pb}$ content reaches its highest value $\left(102.6 \mu \mathrm{g} \mathrm{g}^{-1}\right)$. The $\mathrm{Fe} / \mathrm{Mn}$ ratio increases, and it is very high at the boundary between GZ2 and GZ3 ( 9000, while the average value for the whole core is about 200$)$. In this sub-zone a hiatus occurs. The increased concentrations of metal elements, together with increased content of mineral matter, may be an effect of decomposition of organic matter.

- GZ3 (6-0 cm); from 1960-1990 AD to 2016 AD; this zone reflects modern times, ca. the past 40 years. It is characterized by increasing content of OM (up to over 95\%), Ca, Mg, Mn, Cu, Zn, and Ni and decreasing concentrations of $\mathrm{Pb}$. The concentrations of $\mathrm{Na}, \mathrm{Mn}, \mathrm{Cu}, \mathrm{Zn}$, and $\mathrm{Ni}$ are the highest of those in the entire core, reaching $617.1,881,139.2,403.6$ and $186.8 \mu^{-1}$, respectively).

\section{Pb ISOTOPIC COMPOSITION}

The lead isotopic composition is reported in Table 4. The values of ${ }^{208} \mathrm{~Pb} /{ }^{204} \mathrm{~Pb},{ }^{207} \mathrm{~Pb} /{ }^{204} \mathrm{~Pb}$ and ${ }^{206} \mathrm{~Pb} /{ }^{204} \mathrm{~Pb}$ ratios in the deepest part of the peat core $(283 \mathrm{~cm})$ are $38.9863 \pm 0.0028$ (maximum value), $15.6997 \pm 0.0010$ and $19.1401 \pm 0.0012$, respectively. The values of ${ }^{207} \mathrm{~Pb} /{ }^{204} \mathrm{~Pb}$, and ${ }^{206} \mathrm{~Pb} /{ }^{204} \mathrm{~Pb}$ ratios slightly increase with decreasing depth in the lower part of the core (between $\sim 4200 \mathrm{BC}$ and $1530 \mathrm{BC}$ ) and reach their maxima at a depth of $219 \mathrm{~cm}: 15.7115 \pm 0.0007$ and $19.2225 \pm 0.0008$, respectively. The value of the ${ }^{208} \mathrm{~Pb} /{ }^{204} \mathrm{~Pb}$ ratio generally decreases upwards along the core. From about $23 \mathrm{~cm}$ depth $(\sim 580 \mathrm{AD})$ the values of all measured $\mathrm{Pb}$ ratios $\left({ }^{208} \mathrm{~Pb} /{ }^{204} \mathrm{~Pb}\right.$, 


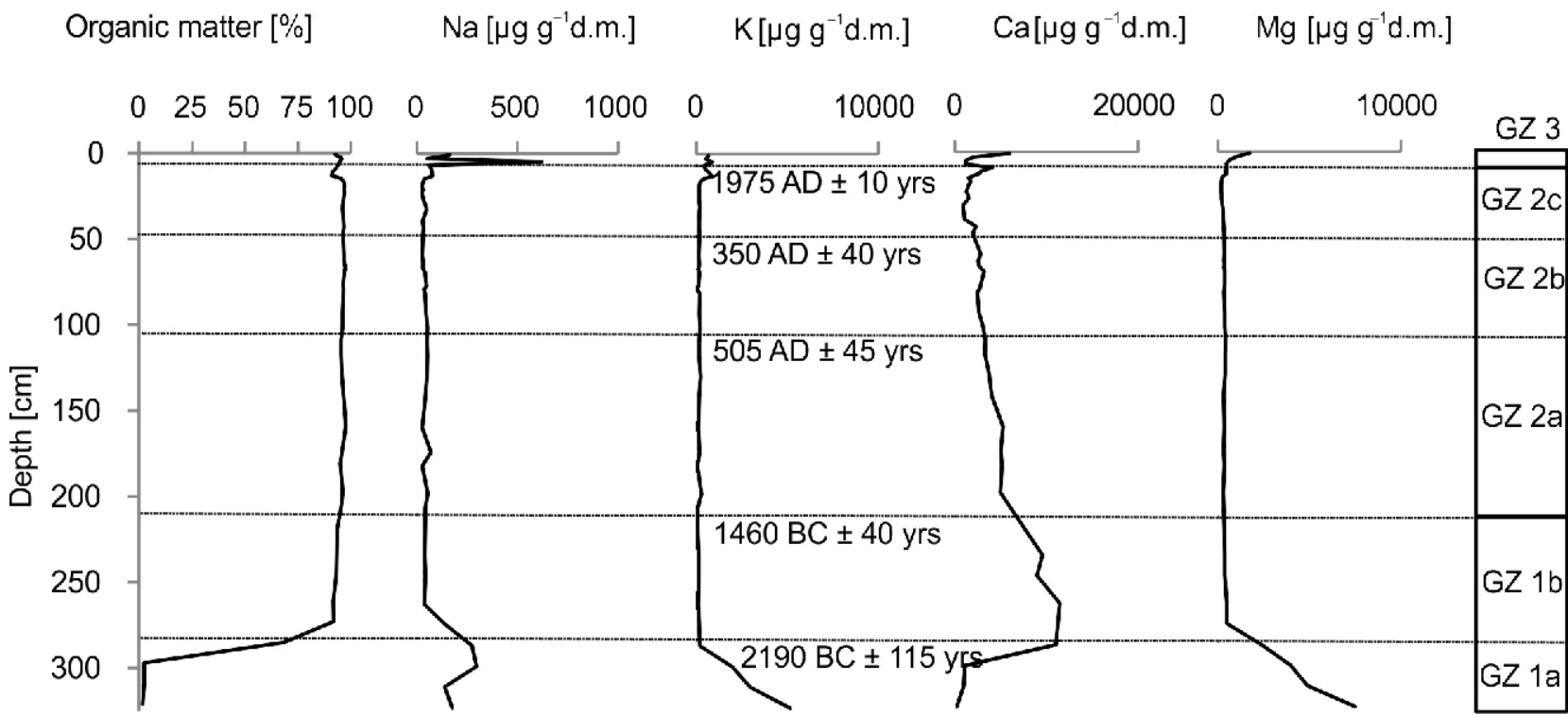

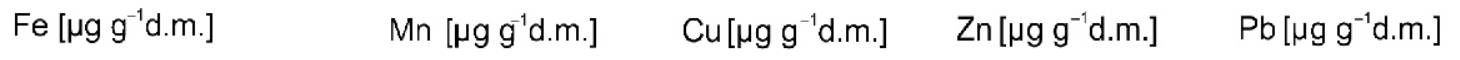

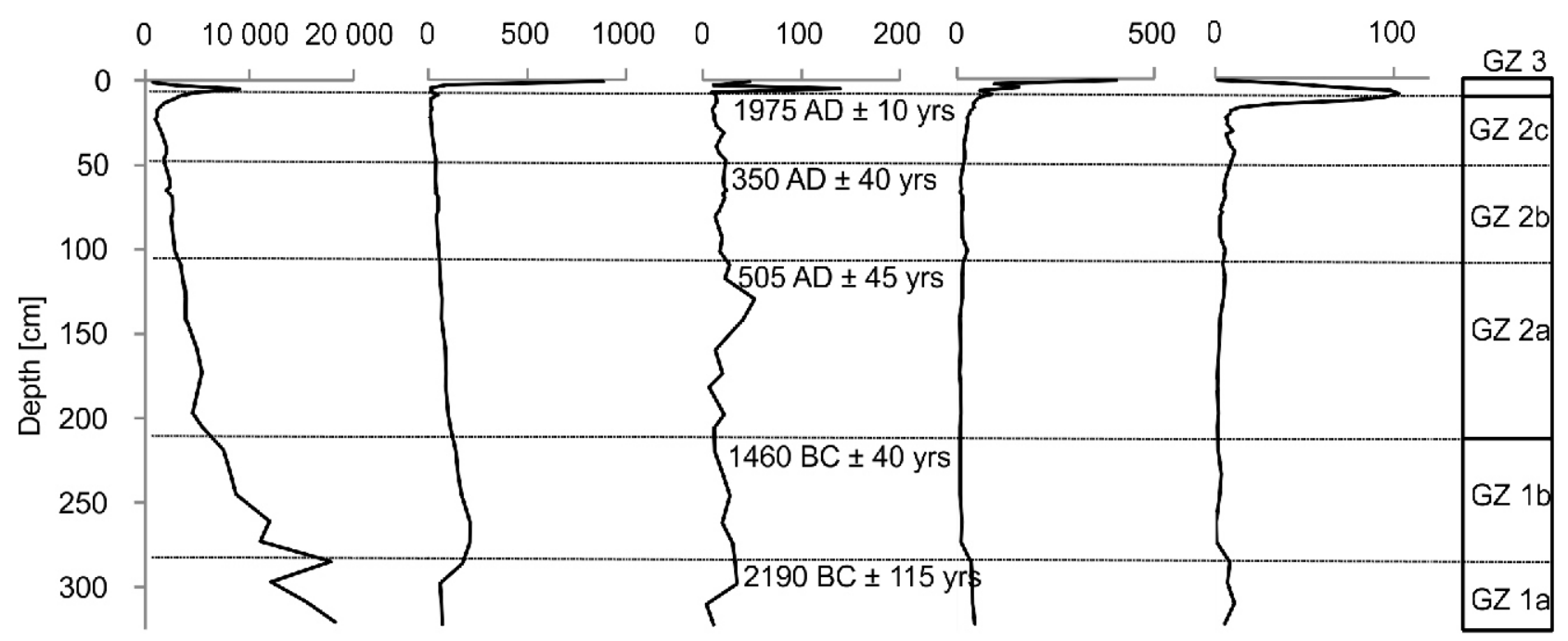
$\mathrm{Ni}\left[\mu \mathrm{g} \mathrm{g}{ }^{-1}\right.$ d.m.]
$\mathrm{Cr}\left[\mu \mathrm{g} \mathrm{g}^{-1} \mathrm{~d} . \mathrm{m}.\right]$
$\mathrm{Fe} / \mathrm{Mn}$
$\mathrm{Na} / \mathrm{K}$
$\mathrm{Cu} / \mathrm{Zn}$

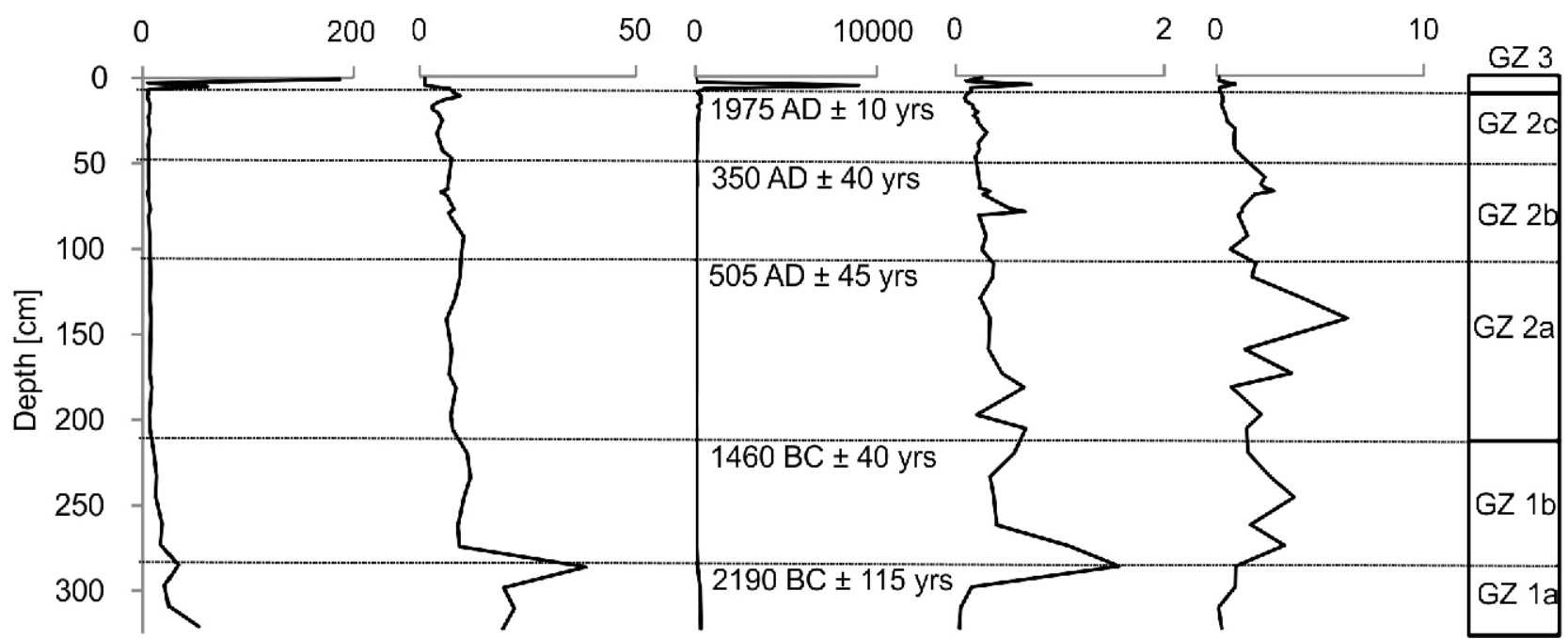

Fig. 5. Concentrations of selected elements, obtained by AAS analysis, contents of organic matter and geochemical indices 


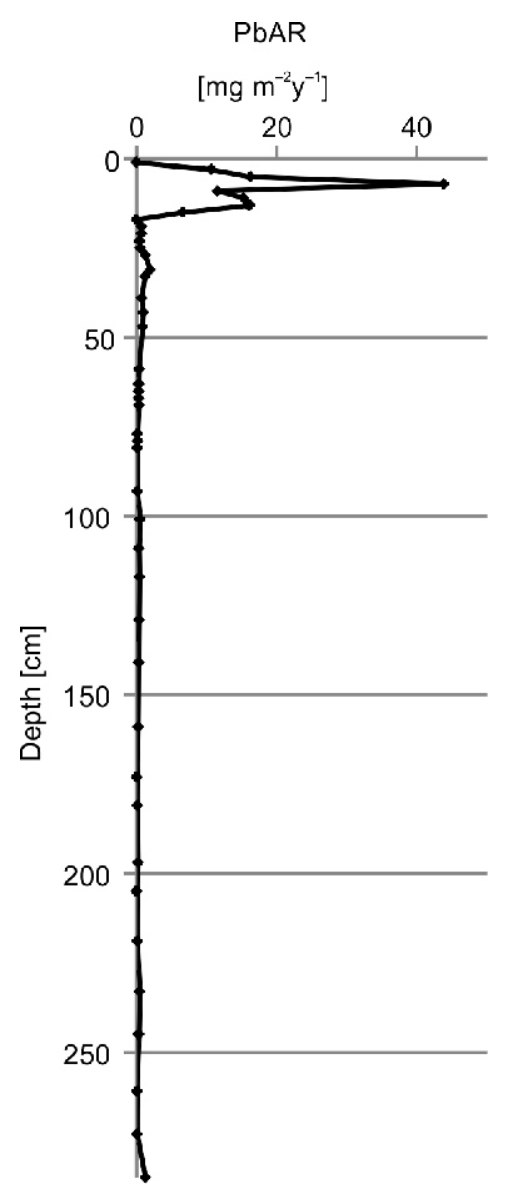

Fig. 6. $\mathrm{Pb}$ accumulation rate in the JB-1 core

${ }^{207} \mathrm{~Pb} /{ }^{204} \mathrm{~Pb}$ and ${ }^{206} \mathrm{~Pb} /{ }^{204} \mathrm{~Pb}$ ) start to decrease more rapidly and at about $6 \mathrm{~cm}$ depth (1975 AD) they reach their minima: $38.1947 \pm 0.0021,15.6128 \pm 0.0007$ and $18.2467 \pm 0.0008$, respectively. This stratum is also the boundary between GZ2 and GZ3. Then, towards the surface (1 $\mathrm{cm}$ depth, present), the values of ${ }^{208} \mathrm{~Pb} /{ }^{204} \mathrm{~Pb},{ }^{207} \mathrm{~Pb} /{ }^{204} \mathrm{~Pb}$, and ${ }^{206} \mathrm{~Pb} /{ }^{204} \mathrm{~Pb}$ ratios increase, reaching $38.2642 \pm 0.0015,15.6260 \pm 0.0006$ and $18.3315 \pm$ 0.0007 , respectively.

These variations clearly coincide with changes in the $\mathrm{Pb}$ concentration. The binary diagram ${ }^{208} \mathrm{~Pb} /{ }^{206} \mathrm{~Pb}$ vs. ${ }^{206} \mathrm{~Pb} /{ }^{207} \mathrm{~Pb}$, shown in Figure 7A, is helpful in determining the origin of lead in the Otrębowskie Brzegi peatland. It includes the isotopic ratios of 29 peat samples, as well as the data from Puścizna Mała and Puścizna Krauszowska peatlands (Fiałkiewicz-Kozieł et al., 2018) and from Słowińskie Błoto peatland (De Vleeschouwer, et al., 2009). The diagram in Figure 7B shows the samples from Otrębowskie Brzegi, grouped by age, with respect to the $\mathrm{Pb}$ isotopic ratios of upper continental crust (UCC, data from Millot et al., 2004) and modern industrial aerosols (Bollhöfer and Rosman, 2001).

Figure 8 shows the relation between $\mathrm{Pb}$ concentration (see Fig. 5) and isotopic composition (Table 4), in order to document any changes in ${ }^{206} \mathrm{~Pb} /{ }^{207} \mathrm{~Pb}$ corresponding to $\mathrm{Pb}$ contamination. The increase in $\mathrm{Pb}$ contamination is strongly associated with an increase in the isotopic ratio $\left(R^{2}=0.9367\right)$.

\section{DISCUSSION}

Palynological data and botanical macrofossils analyzes showed that the development of the peatland is strongly marked through the well-defined presence of Sphagnum and Carex. There are noticeable changes in the species composition of tree stands from the deepest layers toward the surface with proximity to the more open areas. The beginning of the peatland development (fen-type) is visible 2150 BC (Fig. 9). Then, the content of Sphagnum increased up to its maximum $\sim 1120 \mathrm{BC}$, when the peatland evolved into a raised bog. Next, the content of Sphagnum decreased down to a minimum at $100 \mathrm{~cm}$ depth (460 BC), which occurred simultaneously with a maximum of AP. At that time, the PAR and PbAR slowed down. From $\sim 840 \mathrm{BC}$ the first slight increases in $\mathrm{Zn}, \mathrm{Pb}$, and other heavy metal concentrations were observed. In that period, a decrease in AP and increase of Cyperaceae is observeable, which suggests some natural processes leading to deforestation and exposure of the area to increased contamination from the atmosphere. At that level, slight changes in $\mathrm{Pb}$ isotopic composition are visible. The next local minimum of AP, with co-occurrence of an increase in Sphagnum, is visible at about $70 \mathrm{~cm}$ depth ( 100 AD). From that point, an increase in Pb concentration is pronounced. That peat layer corresponds to the beginning of the Roman Period, so changes in chemical composition may be suspected to have an anthropogenic origin. This supposition is supported by changes in $\mathrm{Pb}$ isotopic composition. Additionally, the appearance of Plantago lanceolata at the $B C / A D$ boundary suggests grazing, thus the changes may be connected with deforestation. Between 70 and $45 \mathrm{~cm}$ depth (100-380 AD) a visible change in lead isotopic composition occurs, with co-occurrence of an increase of lead concentration. These changes are obviously associated with human activity. The nearest $\mathrm{Zn}-\mathrm{Pb}$ ore deposit that could be a source of $\mathrm{Pb}$ in $\mathrm{JB}-1$ is in the Olkusz region. It is located $\sim 100 \mathrm{~km}$ to the north of the Orava-Nowy Targ Basin. The values of the ${ }^{206} \mathrm{~Pb} /{ }^{207} \mathrm{~Pb}$ ratio in JB-1 in the Roman Period range between 1.194-1.206; corresponding values for galena ( $\mathrm{Pb}$ ore) from the Olkusz region range between 1.177-1.179 (De Vleeschouwer, 2009), and for peat from the Wolbrom mire between 1.174-1.183 (Pawełczyk et al., 2018a). These findings suggest that ores from the Olkusz region could not be the only source of $\mathrm{Pb}$ in JB-1. Another possible source could be mining activity in the Carpathian region, which started in the Roman Period (Borcoş and Udubaşa, 2012). Between 405 and $585 A D$ a visible increase in ${ }^{206} \mathrm{~Pb} /{ }^{207} \mathrm{~Pb}$ ratio was noticed. This is connected with the Great Migration Time - a period in Europe with extremely cold climate conditions. During that time, human activity decreased. From about 500 AD Calluna vulgaris and Cerealia in co-occurrence of charcoal remains are present, which correlates with deforestation, visible in the AP/NAP ratio. The presence of Ledum palustre, Empetrum, Vaccinium and increasing value of Typha latifolia indicates an increase in humidity. Interestingly, while the general direction of historical settlement in Orava-Nowy Targ Basin was from the east (see Fig. 1C), the appearance of cereal pollen in Otrębowskie Brzegi took place a few hundred years earlier than in Puścizna Wielka (see Krąpiec et al., 2016). About $630 \mathrm{AD}$ (20 cm depth) a sharp increase of $\mathrm{Pb}$ and other heavy metal concentrations in the JB-1 profile is observed. That period also showed a beginning of rapid changes in lead isotopic composition: the ${ }^{206} \mathrm{~Pb} /{ }^{207} \mathrm{~Pb}$ ratio started to decrease. This change 
Lead isotope quotients of samples from the JB-1 core with $2 \sigma$ uncertainty

\begin{tabular}{|c|c|c|c|c|c|c|c|c|c|c|}
\hline $\begin{array}{l}\text { Depth } \\
{[\mathrm{cm}]}\end{array}$ & ${ }^{08} \mathrm{~Pb} /{ }^{204} \mathrm{~Pb}$ & $2 \sigma$ & ${ }^{207} \mathrm{~Pb} /{ }^{204} \mathrm{~Pb}$ & $2 \sigma$ & ${ }^{206} \mathrm{~Pb} /{ }^{204} \mathrm{~Pb}$ & $2 \sigma$ & ${ }^{208} \mathrm{~Pb} /{ }^{206} \mathrm{~Pb}$ & $2 \sigma$ & ${ }^{206} \mathrm{~Pb} /{ }^{207} \mathrm{~Pb}$ & $2 \sigma$ \\
\hline 1 & 38.264153 & 0.001528 & 15.626005 & 0.000610 & 18.331530 & 0.000690 & 2.087357 & 0.000033 & 1.173142 & 0.000015 \\
\hline 5 & 38.194683 & 0.002120 & 15.615223 & 826 & 3696 & 846 & 3230 & 0.000048 & 1.168520 & 0.000022 \\
\hline 7 & 38.197218 & 0.00197 & 15.61 & 0.000718 & 18.25 & 0.00 & 2.09 & 0.00 & 056 & 0.000016 \\
\hline 9 & 38.222210 & 0.002120 & 4909 & 0.000838 & 18.268449 & 0.001022 & 2.092295 & 0.000044 & 1.169936 & 0.000017 \\
\hline 11 & 38.256788 & 0.002220 & 15.6 & 0.00 & 18.2 & 26 & $2.0 \mathrm{~s}$ & 0.0 & 1.1 & 0.0 \\
\hline 13 & 38.290174 & 0.001842 & 15.61 & 0.000650 & 18.3 & 0.000752 & 2.090665 & 0.000043 & 1.172586 & 0.000015 \\
\hline $15^{*}$ & 38.364760 & 0.002080 & 15.6 & 0.0 & 243 & 0.00 & 2.08 & 32 & 1.1 & 0. \\
\hline $15^{*}$ & 38.366522 & 0.002520 & 15.628103 & 0.000918 & 5938 & 0.001022 & 2.086763 & 0.000046 & 1.176466 & 0.000015 \\
\hline 17 & 38.500809 & 0.00 & 15.6 & & 47 & 0.0 & 2.0 & & 34 & 0.0 \\
\hline 19 & 38.65 & 0.001814 & 15.661787 & 0.000714 & 9403 & 0.000842 & 2.065828 & 0.000036 & 589 & 0.000016 \\
\hline 21 & 38.676215 & 0.001604 & 15.6 & 0.00 & 735 & 32 & 2.0 & 39 & 029 & 017 \\
\hline 23 & 38.79 & 0.002200 & 15.679210 & 0.000792 & 18.881939 & 0.001018 & 2.054439 & 0.000039 & 1.204266 & 0.000017 \\
\hline 25 & 38.8 & 0.00 & 15.6 & 48 & 47 & 0.00 & 2.0 & 35 & 205 & 016 \\
\hline 27 & 38.8 & 0.001850 & 15.681871 & 0.000718 & 18.899300 & 0.000866 & 2.053450 & 032 & 5169 & 0.000014 \\
\hline 29 & 38.7 & 0.00 & 15.6 & 0.00 & 24 & 0.00 & 2.05 & 035 & 579 & 015 \\
\hline 31 & 38.827412 & 0.001450 & 15.685340 & 0.000588 & 18.920423 & 0.000708 & 2.052163 & 027 & 1.206249 & 0.000013 \\
\hline 33 & 38.8 & 0.001598 & 15.6 & 0.00 & 195 & 0.00 & 2.05 & 032 & 757 & 0.000014 \\
\hline 41 & 38.8 & 0.001980 & 15.682493 & 0.000820 & 18.905009 & 0.001032 & 2.053016 & 0.00 & 1.205485 & 0.000015 \\
\hline 45 & 38.627465 & 0.001466 & 15.6 & 0.000 & 18.6 & 0.00 & 2.06 & 0.00 & 726 & 0.000015 \\
\hline 53 & 763 & 0.002920 & 15.679664 & 0.001010 & 18.907427 & 0.001010 & 2.052136 & 0.00 & 1.205857 & 0.000016 \\
\hline 61 & 38.797903 & 0.002240 & 15.682689 & 0.000870 & 18.9 & 0.00 & 2.052607 & 0.00 & 1.205281 & 0.000014 \\
\hline 69 & 38.65 & 0.002020 & 15.663161 & 0.000752 & 18.7 & 862 & 2.06 & 0.0 & 953 & 0.00 \\
\hline 77 & 38.862397 & 0.002620 & 15.690569 & 0.000950 & 18.998 & 0.001112 & 2.045606 & 0.000040 & 1.210820 & 0.000017 \\
\hline 85 & 38.866721 & 0.002220 & 15.693928 & 0.000758 & 19.008371 & 0.000852 & 2.04 & 041 & 193 & 0.000017 \\
\hline 113 & 38.859943 & 0.002300 & 15.690284 & 0.000872 & 19.023683 & 0.001002 & 2.042718 & 0.000035 & 1.212450 & 0.000016 \\
\hline 145 & 38.916753 & 0.002540 & 15.700797 & 0.000886 & 19.136266 & 0.001154 & 2.03 & 0.000033 & 809 & 0.000014 \\
\hline 185 & 38.944079 & 0.001486 & 15.706575 & 0.000566 & 19.182106 & 0.000746 & 2.030176 & 0.000033 & 1.221279 & 0.000015 \\
\hline 219 & 38.955528 & 0.001904 & 15.711526 & 0.000728 & 19.222495 & 0.000832 & 2.026572 & 0.000040 & 1.22 & 0.000018 \\
\hline 249 & 38.938959 & 0.002140 & 15.705576 & 0.000874 & 19.179028 & 0.001068 & 2.030290 & 0.000030 & 1.221160 & 0.000014 \\
\hline 283 & 38.986251 & 0.002840 & 15.699702 & 0.000982 & 19.140067 & 0.001174 & 2.036933 & 0.000038 & 1.219136 & 0.000016 \\
\hline
\end{tabular}

* - replicates 


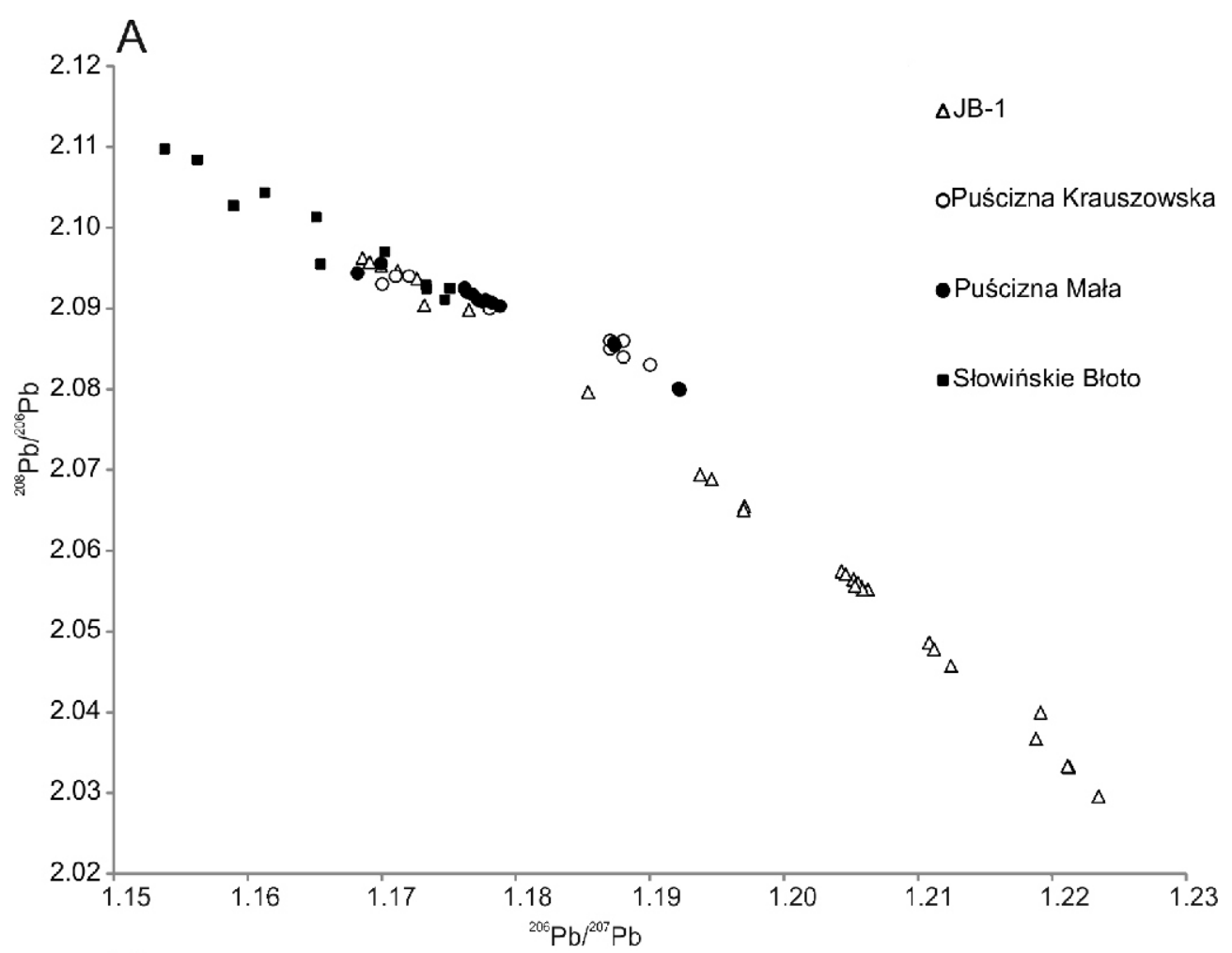

B

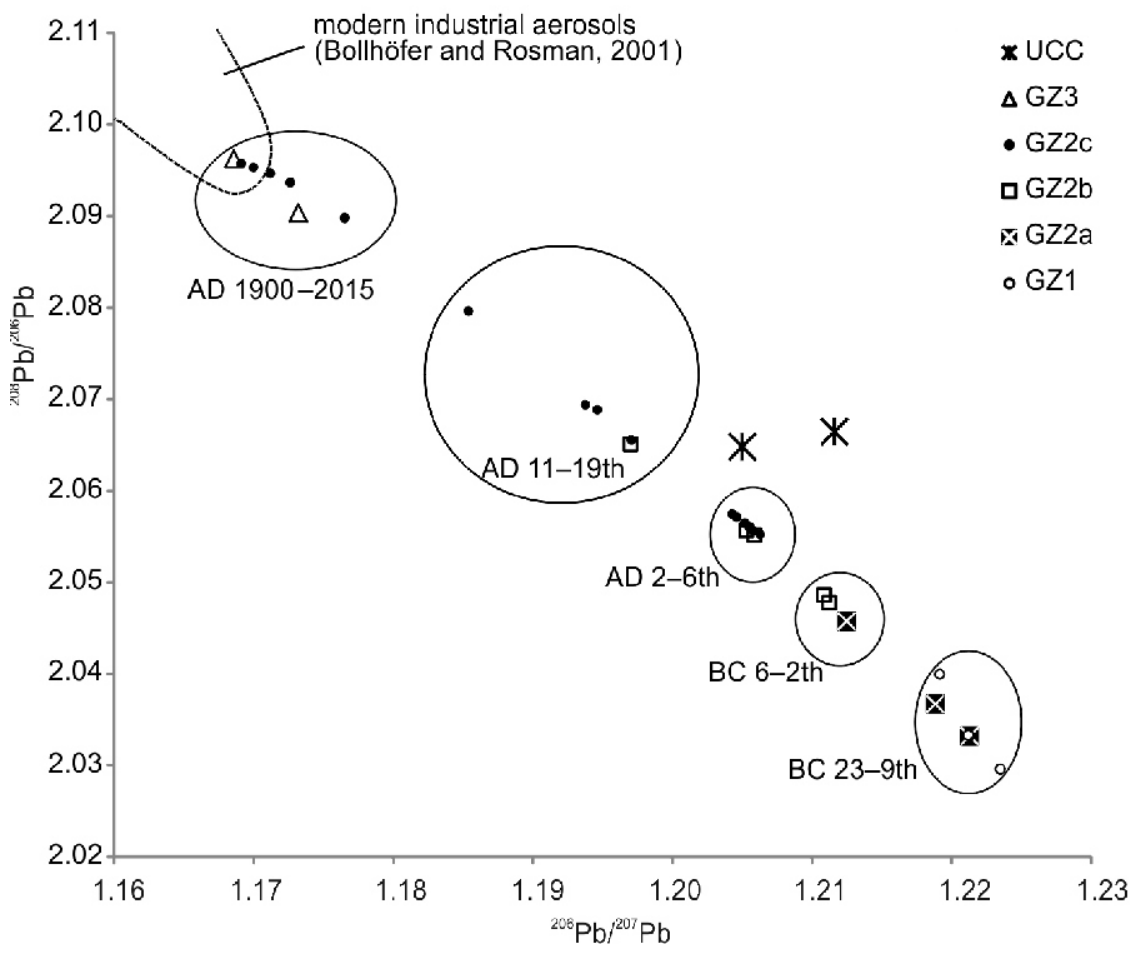

Fig. 7. ${ }^{208} \mathrm{~Pb} /{ }^{206} \mathrm{~Pb}$ versus ${ }^{206} \mathrm{~Pb} /{ }^{207} \mathrm{~Pb}$ diagrams

A - peat samples from Otrębowskie Brzegi (this work), 14 samples from Puścizna Mała, 10 samples from Puścizna Krauszowska (Fiałkiewicz-Kozieł et al., 2018) and 12 samples from Słowińskie Błoto (De Vleeschouwer et al., 2009); B - peat samples from Otrębowskie Brzegi distinguished on the basis of geochemical zones (GZ 1-3), modern urban airborne particles from Europe (Bollhöfer and Rosman, 2001) and Upper Continental Crust (UCC) (Millot et al., 2004); the error bars are negligible 


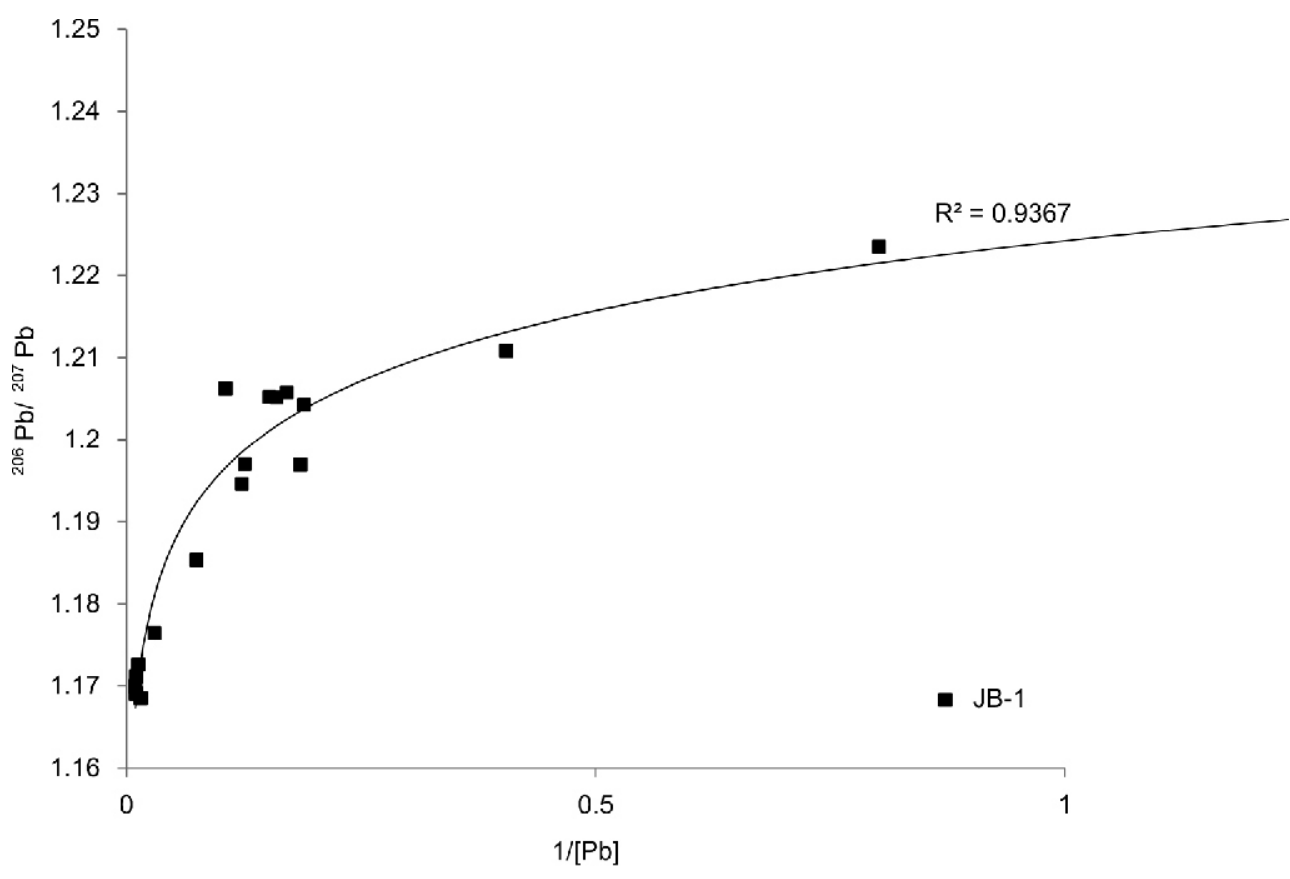

Fig. $8{ }^{206} \mathrm{~Pb} /{ }^{207} \mathrm{~Pb}$ vs. 1/Pb binary diagram, distinguishing the geochemical zones in JB-1, constructed by combining ${ }^{206} \mathrm{~Pb} /{ }^{207} \mathrm{~Pb}$ data from Table 4 with $\mathrm{Pb}$ concentration data (see Fig. 5)

is connected with a strong anthropogenic impact, i.e. mining, smelting, coal combustion, etc. Similar changes have been noticed in other peatlands in the Orava-Nowy Targ Basin, including Puścizna Mała and Puścizna Krauszowska at a similar time (606 AD in Puścizna Mała and 625 AD in Puścizna Krauszowska; Fiałkiewicz-Kozieł et al., 2018). A local minimum of Sphagnum is also visible. From that time the level of AP decreased rapidly, a likely effect of deforestation and agricultural cultivation in the neighborhood of the peatland. The presence of charcoal suggests that forests were burned to clear areas for cultivation. Between 640 and 1905 AD there was a period of hiatus. At about $10 \mathrm{~cm}$ depth ( 1945 AD), a maximum concentration of $\mathrm{Pb}$ and minimum of $\mathrm{AP}$ were observed. At that time the presence of Erica tetralix is visible. It is a very rare species, occurring mostly in the northern part of Poland, so its presence in Orava-Nowy Targ Basin needs additional research. It may be an effect of animal or human migrations. This was a time of total disappearance of Sphagnum, representing the end of peatland development, with clear symptoms of anthropogenic desiccation (changes of LOI, palynological composition). It was the time of maximum anthropogenic impact, including deforestation, agriculture, mining, industry, and coal combustion. This impact is also consistent with changes in geochemical composition, such as increases in $\mathrm{K}$ and heavy metal concentrations, and in $\mathrm{Pb}$ isotopic ratios. The ${ }^{206} \mathrm{~Pb} /{ }^{207} \mathrm{~Pb}$ ratio reaches its minimum value (1.169) during this period. The decrease may have been influenced by waste incinerators that were built in the Czech Republic and Slovakia at the beginning of the 20th century $A D$, as well as an introduction of leaded gasoline. Average values of the ${ }^{206} \mathrm{~Pb} /{ }^{207} \mathrm{~Pb}$ ratio for ashes from waste incinerators are 1.14-1.16 (Komárek et al., 2008) and for Polish gasoline, 1.174 (Yao et al., 2015). From that time up to the present, the AP content increases and $\mathrm{Pb}$ content decreases.

The $\mathrm{Pb}$ isotopic analysis supported reconstruction of the lead sources in the peatland. In the binary diagram (Fig. 7B), the samples from Otrębowskie Brzegi are scattered linearly between natural crust and modern urban airborne sources, which suggests a generally undisturbed lead supply and shows the contribution of two main sources of lead:

- the first end-point is characterized by high ${ }^{206} \mathrm{~Pb} /{ }^{207} \mathrm{~Pb}$ (1.224) and low ${ }^{208} \mathrm{~Pb} /{ }^{206} \mathrm{~Pb}(2.027)$ ratios; its total concentration of $\mathrm{Pb}\left(1.25 \mathrm{\mu g} \mathrm{g}^{-1}\right)$ corresponds to the oldest GZ1 samples (4200-1460 BC). The first end-point is compatible with a natural crustal source represented by UCC (Millot et al., 2004);

- the second end-point is located on the opposite site of the diagram and is characterized by low ${ }^{206} \mathrm{~Pb} /{ }^{207} \mathrm{~Pb}$ (1.169) and high ${ }^{208} \mathrm{~Pb} /{ }^{206} \mathrm{~Pb}(2.093)$ ratios. At this point the total concentration of $\mathrm{Pb}$ is $38.67 \mu \mathrm{g} \mathrm{g}^{-1}$. This end-point is connected with the GZ3 and indicates modern airborne particles as a source of lead pollution in the peat samples.

\section{CONCLUSIONS}

The profile JB-1 from Otrębowskie Brzegi represents the time period from $4200 \mathrm{BC}$ to the present (2016 AD), however, the interpretation of the oldest gyttja sample should be qualified because of a probable aging effect. In the deepest layer (321-205 cm), which corresponds to the period from $4370-3985 \mathrm{BC}$ to $1500-1310 \mathrm{BC}$, the peat is undisturbed and no evidence of human activity is observed. Using that layer as a natural background allowed for the reconstruction of $\mathrm{Pb}$ pollution in this area in the past.

As the $\mathrm{Pb}$ isotopic analysis showed, the deepest and oldest samples are associated with upper continental crust, while the upper part of the core, which corresponds to the period from the Industrial Revolution to the present, is characterized by modern airborne pollution.

From about $140 \mathrm{~cm}$ depth (840 BC) a slight increase of heavy metal concentrations was noted. Taking into account the results of palynological analysis, we infer that this effect was caused by natural processes. However, at the same time, 


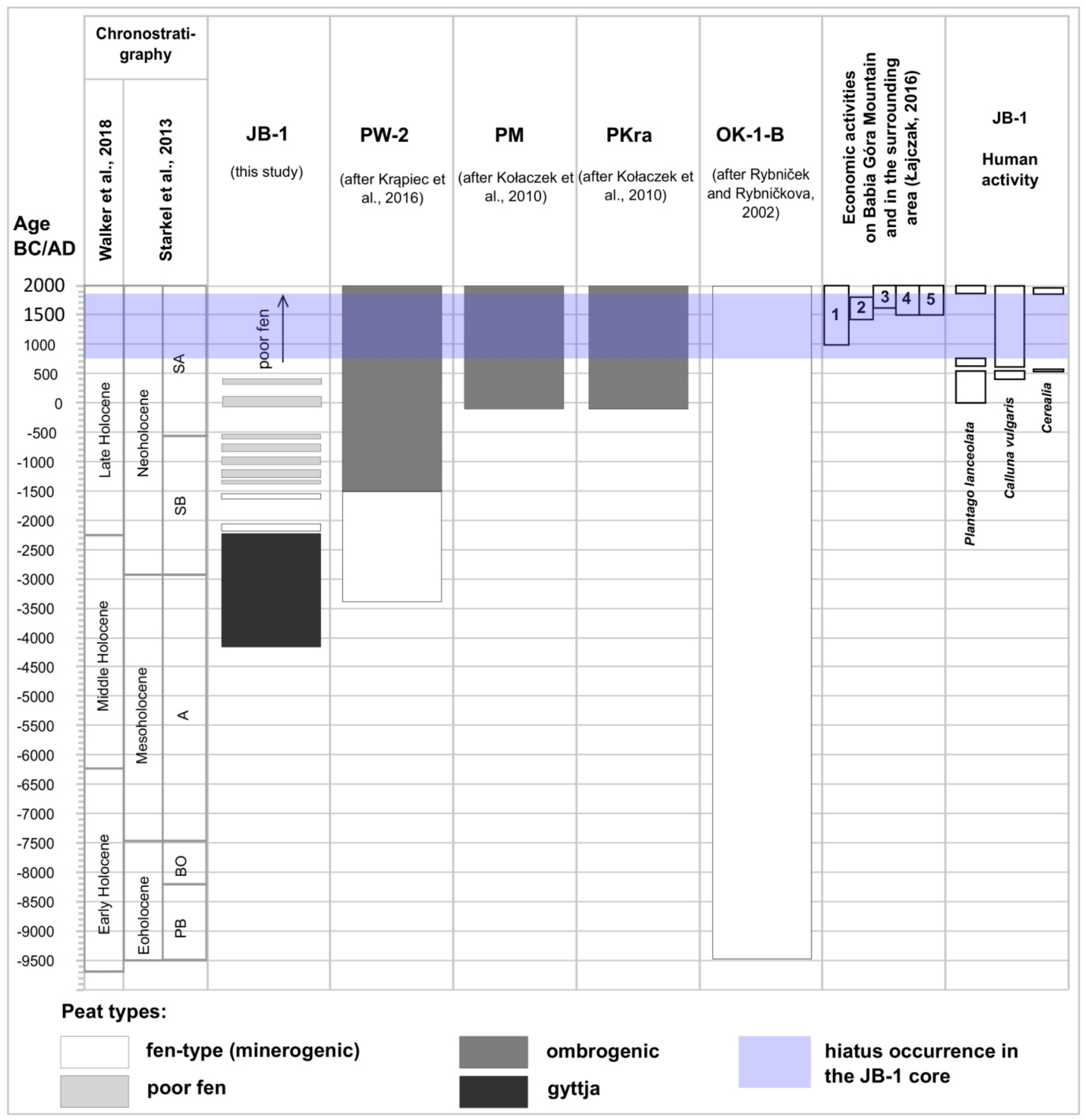

Fig. 9. Human impact recorded in the Otrębowskie Brzegi peatland (on the basis of pollen analysis), in comparison with other peatlands from the Orava-Nowy Targ Basin (Rybniček and Rybničkova, 2002; Kołaczek et al., 2010; Krąpiec et al., 2016)

PW-2 - Puścizna Wielka; PM - Puścizna Mała; PKra - Puścizna Krauszowska; OK-1-B - Bobrov; economic activities after Łajczak (2016): 1 - settlement and agriculture; 2 - flysch rocks extraction; 3 - cutting down forests for pastoralism; 4 - pastoralism; 5 - forestry and wood management; Holocene chronostratigraphy after Starkel et al. (2013), Walker et al. (2018) 
a slight increase in ${ }^{208} \mathrm{~Pb} /{ }^{206} \mathrm{~Pb}$ ratio as well as a decrease in ${ }^{206} \mathrm{~Pb} /{ }^{207} \mathrm{~Pb}$ ratio was observed, which may reflect some human activities, such as smelting. The next well-marked changes in chemical composition, including changes in $\mathrm{Pb}$ isotopic ratios, are connected with deforestation and grazing in the Orava-Nowy Targ Basin. These observations may also reflect some mining and smelting occurring in the Carpathian or Olkusz regions during the Roman Period. The increase of $\mathrm{Zn}$ and $\mathrm{Pb}$ concentrations, correlated with significant changes in lead isotopic composition and the presence of Plantago lanceolata, indicates the activity of the Przeworsk Culture people (see Fig. 9). A period of decreased human activity, supported by $\mathrm{Pb}$ isotopic changes, was noticed during the Great Migration Time, between the 5th and 6th centuries AD.

The top $30 \mathrm{~cm}$ of the profile (corresponding to a period from $\sim 500 \mathrm{AD}$ to the present), given the presence of anthropogenic indicators such as Calluna vulgaris and cereal pollen grains, indicates fires/burning and human activity (see Behre, 1981). Changes in chemical composition indicate that as well. At the end of the hiatus that occurred about 1890 AD more rapid increases of $\mathrm{Pb}$ concentration and ${ }^{208} \mathrm{~Pb} /{ }^{206} \mathrm{~Pb}$ ratio were observed. That was also a period of an abrupt increase of $\mathrm{PbAR}$ linked to intensive human activities such as coal combustion, waste incineration, and smelting during the industrial period and also to the introduction of leaded gasoline. The maximum of lead concentration occurred about 1960 AD as a direct effect of fuel combustion (leaded gasoline) and intensified industry after the Second World War. After 1970, the level of Pb pollution decreased, consistent with the withdrawal of leaded gasoline. From the second half of the 20th century AD, the peatland deteriorated and became overgrown by trees.

The geochemical pattern of the Otrębowskie Brzegi peatland as well as its lead isotopic composition during the 19th and 20th centuries is similar to that of other peatlands from the Orava-Nowy Targ Basin, i.e. Puścizna Krauszowska and Puścizna Mała. The patterns, however, differ in earlier periods While there was a hiatus in JB-1, disturbances were observed in the other two peatlands (see Fiałkiewicz-Kozieł et al., 2018). In comparison to the Słowińskie Błoto peatland, differences in lead isotopic composition are apparent, especially in the top layers of the profiles, where regional pollution is more pronounced.

Because of a hiatus in the profile, interpretation of the portion between 19 and $16 \mathrm{~cm}$ depth (640-1890 AD) should be made with caution. The maxima of heavy metal concentrations were found immediately after the hiatus, which is why we infer that the hiatus was caused by desiccation of the peatland and decomposition of peat.

This work shows the usefulness of peatlands, including poor fens, as natural archives of palaeoenvironmental information, especially in terms of anthropogenic influence. Our results complement research on old mining and metallurgy in Central Europe, indicating peaks in metal production over some time periods, during which production was thought to be low. However, the analyses should be viewed with caution for the portion of the profile corresponding to the hiatus. Lead concentrations and stable lead isotopes are very helpful tools in reconstruction of anthropogenic atmospheric contamination in the past, at both local and regional scales.

Acknowledgments. Work related to the measurement of lead isotopes was funded by the Walloon Region under the framework of the MSWiA and WBI - bilateral agreements between Poland and Belgium (WBI 2017-2019; PI: N. Fagel, B. Sensuła). F.P. would like to thank people from the University of Liège: J. Ottën for his assistance and help during chemical preparation and M. Allan for helpful consultations and advice. The authors would like to acknowledge N. Mattielli and the workers from the ULB G-Time Laboratory for ICP-MS analyses. We would like to thank the two reviewers for careful reading of our manuscript. Their constructive comments and suggestions helped to improve the quality of this manuscript. We would also like to thank the Editor-in-Chief of the journal, Prof. M. Krąpiec, for thorough editorial handling.

\section{REFERENCES}

Barber, K.E., Chambers, F.M., Maddy, D., 2003. Holocene palaeoclimates from peat stratigraphy: macrofossil proxy climate records from three oceanic raised bogs in England and Ireland. Quaternary Science Reviews, 22: 521-39.

Behre, K.E., 1981. The interpretation of anthropogenic indicators in pollen diagrams. Pollen et spores, 23: 225-245.

Beug, H.J., 2004. Leitfaden der Pollenbestimmung für Mitteleuropa und angrenzende (Guide to pollen identification for Central Europe and adjacent areas) (in German). VerlBag Dr. Friedrich Pfeil, München.

Bollhöfer, A., Rosman, K.J.R., 2001. Isotopic source signatures for atmospheric lead: the Northern Hemisphere. Geochimica et Cosmochimica Acta, 65: 1727-1740.

Borcoş, M., Udubaşa, G., 2012. Chronology and characterisation of mining development in Romania. Romanian Journal of Earth Sciences, 86: 17-26.

Bronk Ramsey, C., Lee, S., 2013. Recent and Planned Developments of the Program OxCal. Radiocarbon, 55: 720-730.

Bronk Ramsey, C., 2017. Oxcal software version 4.3.2. http://c14.arch.ox.ac.uk/oxcal/OxCal.html

Coggins, A.M., Jennings, S.G., Ebinghaus, R.,2006. Accumulation rates of the heavy metals lead, mercury and cadmium in ombrotrophic peatlands in the west of Ireland. Atmospheric Environment, 40: 260-278.

De Vleeschouwer, F., Fagel, N., Cheburkin, A., Pazdur, A., Sikorski, J., Mattielli, N., Renson, V., Fialkiewicz, B., Piotrowska, N., Le Roux, G., 2009. Anthropogenic impacts in North Poland over the last 1300 years - a record of $\mathrm{Pb}, \mathrm{Zn}, \mathrm{Cu}$, $\mathrm{Ni}$ and $\mathrm{S}$ in an ombrotrophic peat bog. The Science of the Total Environment, 407: 5674-5684.

De Vleeschouwer, F., Chambers, F.M., Swindles, G.T., 2010. Coring and sub-sampling of peatlands for palaeoenvironmental research. Mires and peat, 7 .

Dyakowska, J., 1928. Historia torfowiska „Na Czerwonem” pod Nowym Targiem w świetle analizy pyłkowej (in Polish). Sprawozdanie Komisji Fizjograficznej Polskiej Akademii Umiejętności, 63: 128-150.

Fægri, K., Iversen, J., 1989. Textbook of Pollen Analysis. John Wiley \& Sons, Chichester-New York-Brisbane-Toronto-Singapore.

Fiałkiewicz, B., Śmieja-Król, B., Sikorski, J., Palowski, B., 2008. The minerotrophic peat bog "Bagno Bruch" as a potential archive of past changes in heavy metal concentrations. Proceedings of the 13th International Peat Congress, After Wise Use - 
The Future of Peatlands, 2: 13-16. The International Peat Society, Tullamore.

Fiałkiewicz-Kozieł, B., Śmieja-Król, B., Palowski, B., 2011 Heavy metal accumulation in two peat bogs from Southern Poland. Studia Quaternaria, 28: 17-24.

Fiałkiewicz-Kozieł, B., Kołaczek, P., Piotrowska, N., Michczyński, A., Łokas, E., Wachniew, P., Woszczyk, M., Sensuła, B., 2014a. High-resolution age-depth model of a peat bog in Poland as an important basis for paleoenvironmental studies. Radiocarbon, 56: 109-125.

Fiałkiewicz-Kozieł, B., Śmieja-Król, B., Piotrowska, N., Sikorski, J., Gałka, M., 2014b. Carbon accumulation rates in two poor fens with different water regimes: Influence of anthropogenic impact and environmental change. The Holocene: 1-11 (published online before print)

Fiałkiewicz-Kozieł, B., Kołaczek, B., Michczyński, A., Piotrowska, N., 2015. The construction of a reliable absolute chronology for the last two millennia in an anthropogenically disturbed peat bog: limitations and advantages of using a radio-isotopic proxy and age-depth modelling. Quaternary Geochronology, 25: 83-95.

Fiałkiewicz-Kozieł, B., De Vleeschouwer, F., Mattielli, N., Fagel, N., Palowski, B., Pazdur, A., Smieja-Król, B., 2018. Record of Anthropocene pollution sources of lead in disturbed peatlands from Southern Poland. Atmospheric Environment, 179: 61-68.

Hájková, P., Grootjans, A., Lamentowicz, M., Rybníčková, E., Madaras, M., Opravilová, V., Michaelis, D., Hájek, M., Joosten, H., Wolejko, L., 2012. How a Sphagnum fuscum-dominated bog changed into a calcareous fen: the unique Holocene history of a Slovak spring-fed mire. Journal of Quaternary Science, 27: 233-43.

Hammer, O., Harper, D.A.T., Ryan, P.D., 2001. PAST: Paleontological statistics software package for education and data analysis. Palaeontologia Electronica, 4: 1-9.

Hansson, S.V., Claustres, A., Probst, A., De Vleeschouwer, F., Baron, S., Galop, D., Mazier, F., Le Roux, G., 2017. Atmospheric and terrigenous metal accumulation over 3000 years in a French mountain catchment: Local vs distal influences. Anthropocene, 19: 45-54.

Hołyńska, B., Ostachowicz, B., Ostachowicz, J., Samek, L., Streli, C., Wachniew, P., Węgrzynek, D., 1998. Zmiany stężenia metali ciężkich w torfie z Puścizny Rękowiańskiej (in Polish). Krajowe Sympozjum „Technika w przemyśle, medycynie, rolnictwie i ochronie środowiska", Kraków: 135-140.

Hua, Q., Barbetti, M., Rakowski, A.Z., 2013. Atmospheric radiocarbon for the period 1950-2010. Radiocarbon, 55: 2059-2072.

Ilnicki, P., 1967. Kurczliwość torfów w czasie suszenia w zależności od ich struktury i właściwości fizycznych (in Polish). Zeszyty Problemowe Postępów Nauk Rolniczych, 76: 197-311.

Ilnicki, P., 2002. Torfowiska i Torf (in Polish). Wydawnictwo AR, Poznań.

Jamrichová, E., Hájková, P., Horsák, M., Rybníčková, E., Lacina, A., Hájek, M., 2014. Landscape history, calcareous fen development and historical events in the Slovak Eastern Carpathians. Vegetation history and archaeobotany, 23 497-513.

Jost., H., 1962. O górnictwie i hutnictwie w Tatrach Polskich (in Polish). Wydawnictwa Naukowo Techniczne.

Jost., H., 2004. Dzieje górnictwa i hutnictwa w Tatrach Polskich (in Polish). Towarzystwo Muzeum Tatrzańskiego im. Dra Tytusa Chałubińskiego, Zakopane.

Jost, H., Paulo, A., 1985. Złoża dawne, górnictwo i przemysł (in Polish). In: Atlas Tatrzańskiego Parku Narodowego. Praca zbiorowa. Tatrzański Park Narodowy, Polskie Towarzystwo Przyjaciół Nauk o Ziemi, Zakopane-Kraków.

Kabata-Pendias, A., 2011. Trace elements in soils and Plants. Fourth edition. CRC Press, Boca Raton.

Kac, N.J., Kac, S.W., Skobiejewa, E., 1977. Atlas rastityelnykh ostatkov w torfakh (in Russian). Nedra, Moskwa.

Kołaczek, P., Fiałkiewicz-Kozieł, B., Karpińska-Kołaczek, M., Gałka, M., 2010. The last two millennia of vegetation develop- ment and human activity in the Orawa-Nowy Targ Basin (south-eastern Poland). Acta Palaeobotanica, 50: 133-148.

Komárek, M., Ettler, V., Chrastný, V., Mihaljevič, M., 2008. Lead isotopes in environmental sciences: a review. Environment international, 34: 562-577.

Koperowa, W., 1962. The history of Late Glacial and Holocene vegetation in Nowy Targ Basin. Acta Paleobotanica Polonica, 2: 30-75.

Krąpiec, M., Margielewski, W., Korzeń, K., SzychowskaKrapiec, E., Nalepka, D., Łajczak, A., 2016. Late Holocene palaeoclimate variability: the significance of bog pine dendrochronology related to peat stratigraphy. The Puścizna Wielka raised bog case study (Orawa-Nowy Targ Basin, Polish Inner Carpathians). Quaternary Science Reviews, 148: 192-208.

Lipka, K., Zając, E., 2014. Stratygrafia torfowisk Kotliny Orawsko-Nowotarskiej (in Polish). Art-Tekst, Kraków.

Longman, J., Veres, D., 2016. Base metal pollution as a result of historical ore smelting in the Romanian Carpathians throughout the Holocene. GEOREVIEW: Scientific Annals of Stefan cel Mare University of Suceava. Geography Series, 26: 53.

Longman, J., Ersek, V., Veres, D., Salzmann, U., 2016. The smelting of metals in the Romanian Carpathians throughout the Holocene. EGU General Assembly Conference Abstracts, 18.

Longman, J., Veres, D., Finsinger, W., Ersek, V., 2018. Exceptionally high levels of lead pollution in the Balkans from the Early Bronze Age to the Industrial Revolution. Proceedings of the $\mathrm{Na}$ tional Academy of Sciences, 115: E5661-E5668.

Ładygin, Z., 1984. 7 dni na Orawie Polskiej (in Polish). Przewodnik turystyczny. PTTK Kraj, Warszawa-Kraków.

Łajczak, A., 2009. Development conditions and distribution of peat bogs in the Orava-Nowy Targ Basin (in Polish with English summary). Przegląd Geologiczny, 57: 694-702.

Łajczak, A., 2013. Reduction of the extent of peat deposits and their water retention capacity in the Orava-Nowy Targ Basin and Bieszczady Mts. due to human activity (in Polish with English summary). Przegląd Geologiczny, 61: 532-540.

Łajczak, A., 2016. An outline history of economic activity on Mt. Babia Góra and in the surrounding area (Western Carpathians) (in Polish with English summary). Przegląd Geograficzny, 88: 5-30.

Maciak, F., Liwski, S., 1996. Ćwiczenia z torfoznawstwa (in Polish). Wydawnictwo SGGW, Warszawa.

Maksimow, A., 1965. Torf i jego użytkowanie w rolnictwie (in Polish). PWRiL, Warszawa.

Martínez-Cortizas, A., García-Rodeja, E., Pontevedra-Pombal, X., Nóvoa Muńoz, J., Weiss, D., Cheburkin, A.K., 2002. Atmospheric $\mathrm{Pb}$ deposition in Spain during the last 4600 years recorded by two ombrotrophic peat bogs and implications for the use of peat as archives. The Science of the Total Environment, 292: 33-44.

Mauquoy, D., Engelkes, T., Groot, M.H.M., Markesteijn, F., Oudejans, M.G., van der Plicht, J., van Geel, B., 2002 High-resolution records of late Holocene climate change and carbon accumulation in two north-west European ombrotrophic peat bogs. Palaeogeography, Palaeoclimatology, Palaeoecology, 186: 275-310.

Mauquoy, D., van Geel, B., 2007. Mire and peat macros. In: Encyclopedia of Quaternary Science (ed. S.A. Elias): 2315-2336. Elsevier B.V., Amsterdam.

Michczyńska, D.J., Margielewski, W., 2016. Palaeoenvironmental changes of Orawa-Nowy Targ Basin in the Late Glacial and Holocene recorded in sediments of Grel raised bog. GEOREVIEW: Scientific Annals of Stefan cel Mare University of Suceava. Geography Series, 26: 61-62.

Millot, R., Allègre, C.J., Gaillardet, J., Roy, S., 2004. Lead isotopic systematics of major river sediments: a new estimate of the $\mathrm{Pb}$ isotopic composition of the Upper Continental Crust. Chemical Geology, 203: 75-90.

Moore, P.D., Webb, J.A., Collinson, M.E., 1991. Pollen analysis. Blackwell Science Publishers, Oxford. 
Myślińska, E., 2001. Grunty organiczne i laboratoryjne metody ich badania (in Polish). Wydawnictwo Naukowe PWN, Warszawa.

Novak, M., Pacherova, P., 2008. Mobility of trace metals in pore waters of two Central European peat bogs. Science of the total environment, 394: 331-337.

Olszewski, K., 1988. Warunki klimatyczne Torfowisk Orawsko-Nowotarskich (in Polish). In: Dokumentacja Podstawowa Projektowanego Parku Krajobrazowego Torfowiska Orawsko-Nowotarskie (ed. J. Kondracki), unpublished manuscript. Faculty of Geography and Regional Studies, University of Warsaw.

Pawełczyk, F., Chróst, L., Magiera, T., Michczyński, A., Sikorski, J., Tudyka, K., Zając, E., 2017. Radiocarbon and lead-210 age-depth model and trace elements concentration in the Wolbrom fen (S Poland). Geochronometria, 44: 40-48.

Pawełczyk, F., Michczyński, A., Tomkowiak, J., Tudyka, K. Fagel, N., 2018a. Mid-to Late Holocene elemental record and isotopic composition of lead in a peat core from Wolbrom (S Poland). Mires and Peat, 21.

Pawełczyk, F., Okupny, D., Michczyński, A., 2018b Zróżnicowanie zawartości pierwiastków śladowych w osadach torfowisk Wolbrom i Otrębowskie Brzegi odzwierciedleniem wpływu antropopresji (in Polish). Acta Geographica Lodziensia, 107: 175-190.

Pawlyta, J., Pazdur, A., Rakowski, A., Miller, B.F., Harkness, D.D., 1998. Commissioning of QuantulusTM liquid scintillation beta spectrome-ter for measuring ${ }^{14} \mathrm{C}$ and ${ }^{3} \mathrm{H}$ at natural abundance levels. Radiocarbon, 40: 201-209.

Piotrowska, N., 2013. Status report of AMS sample preparation laboratory at GADAM Centre, Gliwice, Poland. Nuclear Instruments and Methods in Physics Research Section B: Beam Interactions with Materials and Atoms, 294: 176-181.

PN-G-04595, 1997. Torfy i wyroby z torfu. Oznaczanie stopnia rozkładu (in Polish). Polski Komitet Normalizacyjny.

Poller, U., Todt, W., Kohut, M., Janak, M., 2001. Nd, Sr, Pb isotope study of the Western Carpathians: implications for the Paleozoic evolution. Schweizerische Mineralogische und Petrographische Mitteilungen, 81: 159-174

Renson, V., Fagel, N., Mattielli, N., Nekrassoff, S., Streel, M., De Vleeschouwer, F., 2008. Roman road pollution assessed by elemental and lead isotope geochemistry in East Belgium. Applied Chemistry, 23: 3253-3266.

Reimer, P.J., Bard, E., Bayliss, A., Beck, J.W., Blackwell, P.G., Bronk Ramsey, C., Buck, C.E., Cheng, H., Edwards, R.L., Friedrich, M., Grootes, P.M., Guilderson, T.P., Haflidason, H., Hajdas, I., Hatté, C., Heaton, T.J., Hoffmann, D.L., Hogg, A.G., Hughen, K.A., Kaiser, K.F., Kromer, B., Manning, S.W., Niu, M., Reimer, R.W., Richards, D.A., Scott, E.M., Southon, J.R., Staff, R.A., S.M. Turney, C., van der Plicht, J., 2013. IntCal13 and Marine13 radiocarbon age calibration curves 0-50,000 years cal BP. Radiocarbon, 55: 1869-1887.

Rösch, M., Fischer, E., 2000. A radiocarbon dated Holocene pollen profile from the Banat mountains (Southwestern Carpathians, Romania). Flora, 195: 277-86.

Rybníček, K., Rybníčková, E., 1985. A palaecological reconstruction of precultural vegetation in the intermontane basins of the western Carpathians. Ecologia Mediterranea, 11: 27-31.

Rybniček, K., Rybničkova, E., 2002. Vegetation of the Upper Orava region (NW Slovakia) in the last 11000 years. Acta Paleobotanica, 42: 153-170.

Rydlewski, J., Valde-Nowak, P., 1984. Z najdawniejszej przeszłości Orawy (in Polish). Wierchy, 51: 7-25.

Sikorski, J., Bluszcz, A., 2008. Application of $\alpha$ and $\gamma$ spectrometry in the ${ }^{210} \mathrm{~Pb}$ method to model sedimentation in artificial retention reservoir. Geochronometria, 31: 65-75.
Shotyk, W., Weiss, D., Appleby, P.G., Cheburkin, A. K., Frei, R., Gloor, M., Kramers, J.D., Reese, S., Van Der Knaap, W.O., 1998. History of atmospheric lead deposition since 12,370 14C yr BP from a peat bog, Jura Mountains, Switzerland. Science, 281: 1635-1640.

Skripkin, V., Kovaliukh, N., 1998. Recent developments in the proce-dures used at the SSCER Laboratory for the routine preparation of lithium carbide. Radiocarbon, 40: 211-214.

Sławińska, J., Tomkowiak, J., Ligenza, P., Okupny, D., Borówka, R. K., 2018. Rtęć w osadach torfowisk wysokich Kotliny Orawsko-Podhalańskiej (in Polish). IX Sesja Paleolimnologiczna: Dynamika zmian klimatycznych W czwartorzędzie oraz granica późny glacjał/holocen w osadach biogenicznych południowej Polski, Kraków (poster).

Solecki, A., 1977. Osadnictwo na Podhalu: geneza i rozwój ukształtowania przestrzennego (skrót pracy habilitacyjnej) (in Polish). Zeszyty Naukowe Akademii Rolniczej w Krakowie, Rozprawy, 142

Starkel, L., Michczyńska, D., Krąpiec, M., Margielewski, W., Nalepka, D., Pazdur, A., 2013. Progress in the Holocene chrono-climatostratigraphy of Polish territory. Geochronometria, 40: 1-21.

Stockmarr, J., 1971. Tabletes with spores used in absolute pollen analysis. Pollen et Spores, 13: 615-621.

Śmieja-Król, B., Fiałkiewicz-Kozieł, B., Sikorski, J., Palowski, B., 2010. Heavy metal behaviour in peat - a mineralogical perspective. Science of the Total Environment, 408: 5924-5931.

Śmieja-Król, B., Janeczek, J., Bauerek, A., Thorseth, I.H., 2015. The role of authigenic sulfides in immobilization of potentially toxic metals in the Bagno Bory wetland, southern Poland. Environmental Science and Pollution Research, 22: 15495-15505.

Tobolski, K., 2000. Przewodnik do Oznaczania Torfów i Osadów Jeziornych (in Polish). Wydawnictwo Naukowe PWN, Warszawa.

Tołpa, S., Jasnowski, M., Pałczyński, A., 1967. System der genetischen Klassifizierung der Torfe Mitteln-Europas (in German). Zeszyty Problemowe Postępów Nauk Rolniczych, 76: 9-99.

Walanus, A., Nalepka, D., 2004. POLPAL. Application for plotting pollen diagrams, counting pollen grains and performing numerical analysis (with data stored in text files, in MS Excel, Word, Notepad etc.). Instytut Botaniki PAN, Kraków.

Walker, M., Head, M.J., Berkelhammer, M., Björck, S., Cheng, H., Cwynar, L., Fisher, D., Gkinis, V., Long, A., Lowe, J., Newnham, R., Rasmussen, S.O., Weiss, H., 2018. Formal ratification of the subdivision of the Holocene Series/Epoch (QuaternarySystem/Period): two new Global Boundary Stratotype Sections and Points (GSSPs) and three new stages/subseries. Episodes, https://doi.org/10.18814/epiiugs/2018/018016

Weis, D., Kieffer, B., Maerschalk, C., Pretorius, W., Barling, J., 2005. High-precision $\mathrm{Pb}-\mathrm{Sr}-\mathrm{Nd}-\mathrm{Hf}$ isotopic characterization of USGS BHVO-1 and BHVO-2 reference materials. Geochemistry, Geophysics, Geosystems, 6: 1-10.

Wójcikiewicz, M., 1979. Stratygrafia torfowiska Bór na Czerwonem z uwzględnieniem zespołów subfosylnych oraz rozmieszczenia i zróżnicowania współczesnych zbiorowisk roślinnych (in Polish). Zeszyty Naukowe Akademii Rolniczej w Krakowie, 153: 133-193.

Yao, P.H., Shyu, G.S., Chang, Y.F., Chou, Y.C., Shen, C.C., Chou, C.S., Chang, T.K., 2015. Lead isotope characterization of petroleum fuels in Taipei, Taiwan. International Journal of Environmental Research and Public Health, 12: 4602-4616. 